\title{
الاتجاه نحو التعلم النشط وعلاقته بالدافعية للإنجاز ل الدى تلاميذ المدرسة الابتدائية
}

\section{مرفت ابراهيم ابراهيه عوضن}

\section{|الملخص:}

هدف البحث الحالي إلى التعرف على اتجاه التلاميذ نحو التعلم النشط ،ومعرفة العالقة بين

اتجاهاتهم نحو التعلم النشط والدافعية للإنجاز لديهم ومعرفة الفرق بين ذوى الاتجاه الأعلى والأدنى على

الدافعبة للإنجاز، وتكونت عبنة الدراسة من (VVO) تلمبذاً من تلامبذ الصف الخامس والسادس الابتدائي،

وقد أظهرت نتائج الدراسة وجود فروق ذات دلالة احصائية بين متوسط درجات التلاميذ ومتوسط درجات

التلميذات في الددرسة الابتدائية على مقياس الاتجاه نحو التعلم النشط لصالح التلميذات ، كما أوضحت

النتائج وجود ارتباط بين درجات التلاديذ على مقياس الاتجاه نحو التعلم النشط و درجاتهم على الد/فعية

للإنجاز ، كما أثارث نتائج الدراسة إلى وجود فروق دالة إحصائيا بين التلامبذ ذوى الاتجاه الأعلى وذوى لإنى

الاتجاه الأدنى نحو التعلم النشط في الدافعية للإنجاز لصالح التلامبذ ذوى الاتجاه الأعلى نحو التعلم النشط.

\section{Abstract:}

The aim of the current research was to identify the students' attitude towards active learning and detect the relationship between their attitudes towards active learning, Achievement Motivation. It also aimed to detect the difference between those with the highest and the lowest attitude on Achievement Motivation scales. The sample consisted of 775 grade five and six students, The results revealed statistically significant differences between (male-female) students in the attitude towards active learning for girls, The results also showed statistically significant correlation between students' scores on the attitude towards active learning scale and their scores on Achievement Motivation scales. The results also showed statistically significant differences between students with the highest and the lowest attitude towards active learning on achievement motivation for the sake of students with the highest attitude towards active learning.

$$
\begin{aligned}
& \text { المجال التزبوي و الذي يعد النشء لقيادة باقي } \\
& \text { المجالات في المجتمع، ولتحسين جودة حيــاة } \\
& \text { الطالب المدرسية والأسرية و المجتمعية فـى } \\
& \text { ظل هذه التحديات الخارجية و الداخلية ؛ فإن } \\
& \text { ذللك يدعو لتفعيل التعلم الذي يــسـاعد علــى }
\end{aligned}
$$

يتمبـز هـذا العـصر بوجـود العديـد مسن

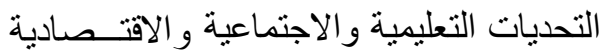
ولمسايرة ركب التقدم فإن هذا يحتاج لبــذل

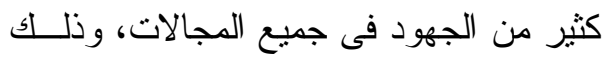
لتحقيق الجودة في جميع المجـــالات و أولهـــا 
التقليدية المعتمدة على الاســتظهار و الحفـــ

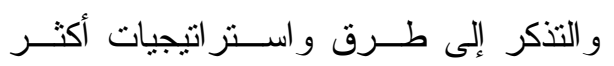

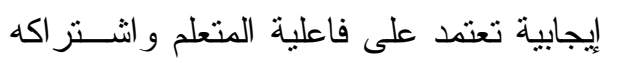

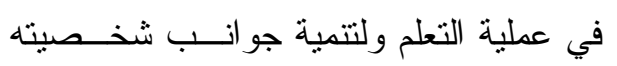

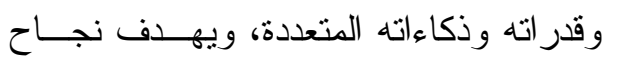
عملية التعلم النشط إلى توسيع دائرة الاختيار

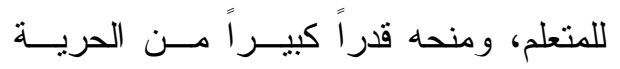

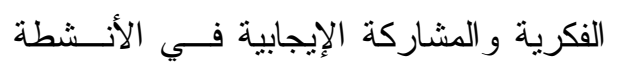
التعليمية. ويعتمد التعلم النـشط علــى وجــود

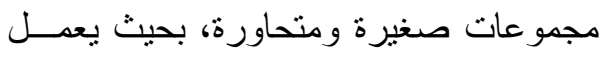

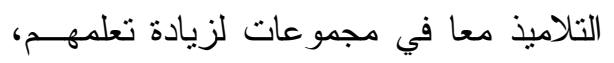
وتفاعلهم، كما يعمل التعلم النشط على تزويد

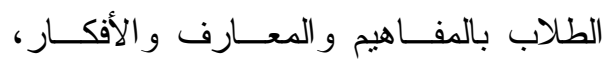

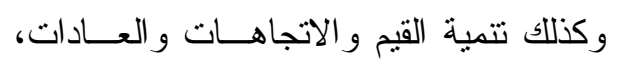
ويكــــهم المهـــار ات، و أســاليب التفكيـــر

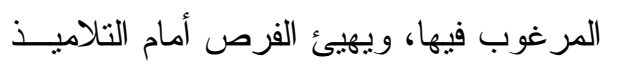

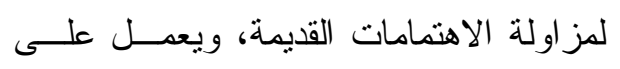
تتمية اهتمامات جديدة أخرى جديــدة لــديهم (عقيل محمود رفاعى، r ( •r، • (1). كما تمنل الدافعية للإنجاز أهمية كبيرة

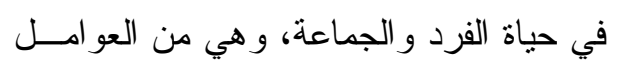

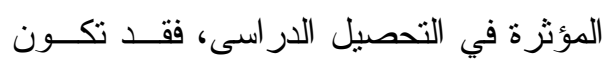
لدى التلميذ قدرة عقلية مناسبة وظروف بيئية

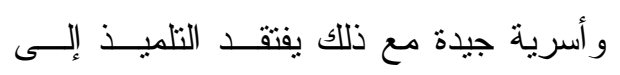

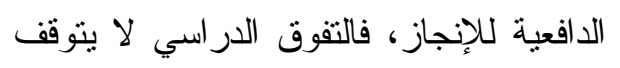

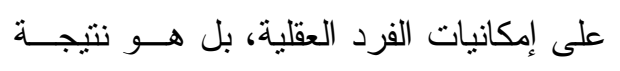

تغيير النظام التقليدي السائد الذي يعمل بـــ المعلم فى الفصل، وتغيير أســلوب إدارتــهـ

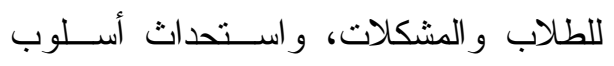

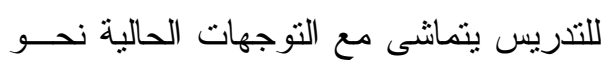
الجودة، ويزيد من دافعية التلميـــ للإنجـــاز

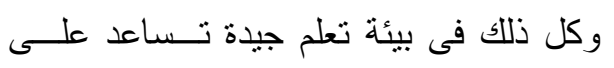
تحقيق الجودة وتدفع نحو الإنجــاز بـصفة دئة عامة .

ومن الاتجاهات الحديثة فـى مجـــال

التربية والتعليم ضرورة التحول من الــتعلم

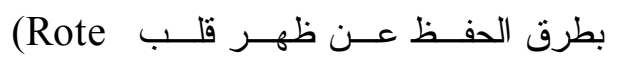

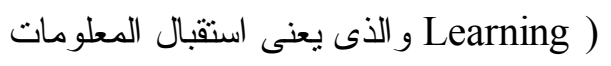
وحفظها ثم استرجاعها إلى مفهـوم الــتعلم النشط ( Active Learning) ويعنى إثر الك

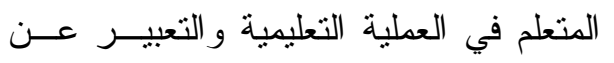
آر ائه و أفكاره بحرية وتبادل الآر اء و الأفكار

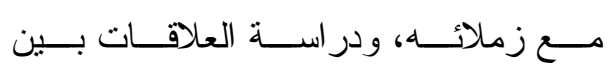
الموضوعات المتباينة و الربط بين المفــاهيم وبما لديه مــن خبــر ات ومعــارف ســــابقة وتوظيف هذه المعلومسـات و الخبــر ات فــى ونى

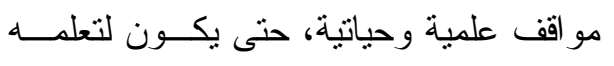

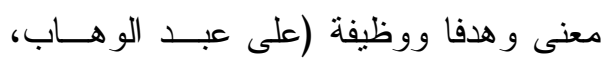
. (r... كما أن الاتجاه نحو التعلم النشط أحد

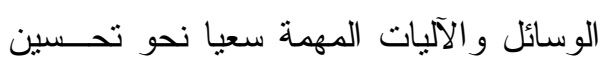
عملية التعليم و التعلم، وتحقيق الجودة الثاملة

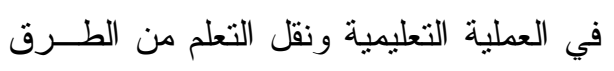


دافعيتهم لإنجاز (إبر اهيم عبد الوكيل الفــار، . . .

$$
\text { . () 1 } 1 \text { ، Y... }
$$

كما تثير فاطمة بنت خلف الزايـدى

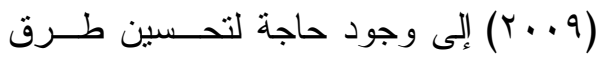

التعلم؛ وذلك بالتوجه نحو اســتخدام الــتعلم

النشط، التي لاقت إقبالا ونجاحا على الصعيد

العالمى والإقليمى، وذلك من أجل دفع المتعلم

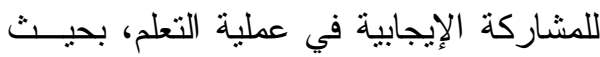

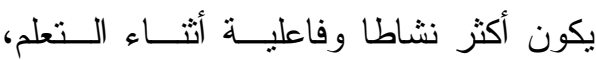

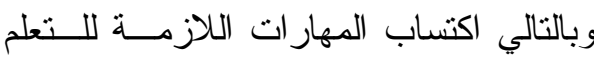

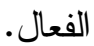

ويزيد الاتجاه نحو التعلم النشط مــن

تحمل الطالب لمسئولية ما يتعطىــه، وحـبـ

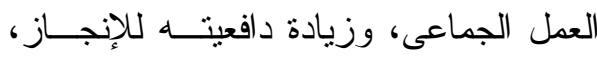

و التحصيل الدراسى بما يحقق عمليات الفهم، و الاستيعاب، و التمثيل، و الإضافة.

ولم يجد الاتجاه نحو الـتـعلم النـشط

الاهتمام الكافى من الدراسات حيث اهتمــت

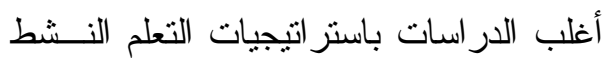

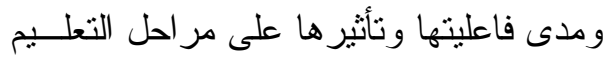

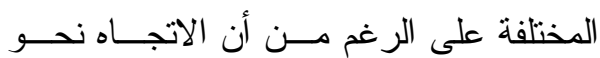

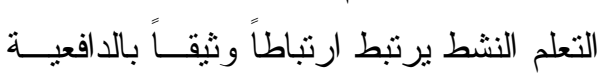

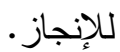

وتكمن مشكلة الدراسة الحاليــة فــي

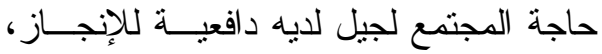

وقادر على تحمل المسئولية، ولديـــه القــدرة
العديد مــنـن العو امـــل الدافعيـــة و الانفعاليـــة

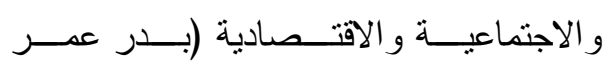

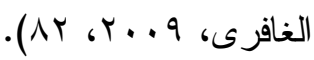

ومن ناحية أخرى يعتقد الكثيرون ممن

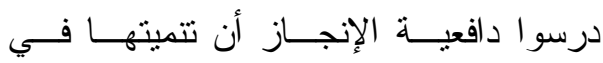
المدارس وفــى غيرهـــــــن المؤسـسات الاجتماعية تؤثز على التلاميــذ، و انجــاز هم المدرسي، و الاهتمام بالدر اســـة وبالتكليفــات المدرسية، و الحرص على النجاح، وتفـــوقهر الدراسي ثم تتعكس على نحو إيجابي علــى ولى اقتصاد المجتمع وتقدمه التكنولوجي (فتحسي

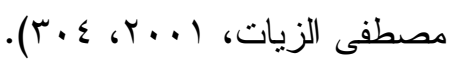
مشكلة البحث: الاتجاهــات دور ا مههـــــــي حيــاة

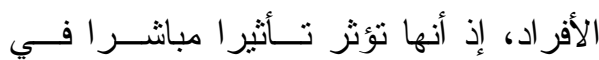
سلوكهم، حيث يمكن النظر إلى الاتجاهـات على أساس أنها نوع من الدوافع الاجتماعية

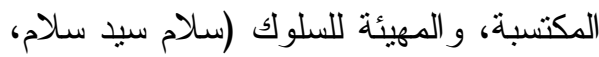
.$(976) 99$.

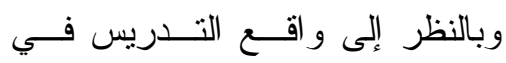

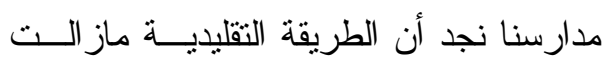
تشغل حيز ا كبير ا بين الطرق و الأساليب التي لفي يستخدمها المعلم داخل الفصل، وبذلك أصبح

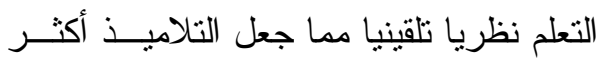
سلبية و اعتمادا في تحصيلهم على مسساعدة

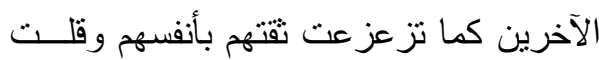


•. ت تحديد الفروق بين تلاميــذ وتلميــذات

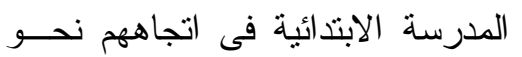

التعلم النشط.

• . . تحديد الفروق بين ذوي الاتجاه الأعلى وذوي الاتجاه الأدنى من التلاميذ نحو دوي الانداه التعلم النشط علـــى مقيــاس الدافعيـــة ل لإنجاز

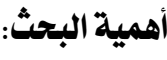
• - توجيه اهتمام المعلمين و المربين إلـى

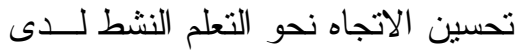
التلاميذ، و إتاحسـة الفرصـــة أمـــامهم ليكونو ا متعلمين نشيطين حيــث وأنـــه يؤثز على الدافعية للإنجاز لليهم.

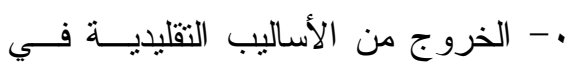

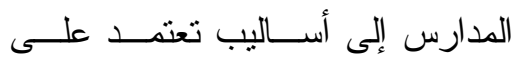
إيجابية المتعلم وتفاعله.

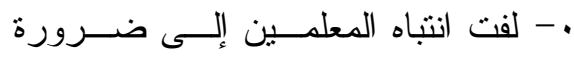

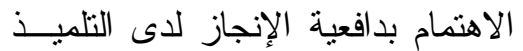
وكونها شرط أساسي فى عملية التعلم الجيد.

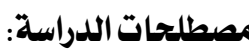

Attitude الاتجاه نحو التعلم النــشط - . :towards Active learning

تعرف الباحثة الاتجــاه نحـــو الــتعلم

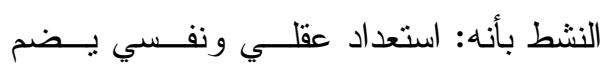

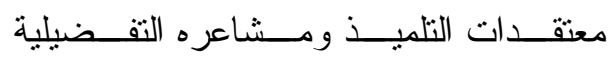
و الانفعالية نحو التعلم النشط ويتكــون لــدى

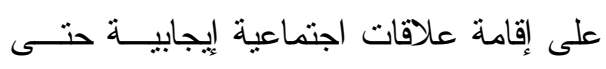
يقدر على العمل في مجموعات من زملائــهـ ويكون قادر على النهوض بالمجتمع في كافة

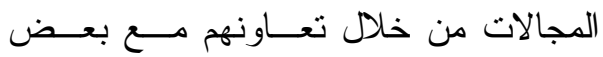

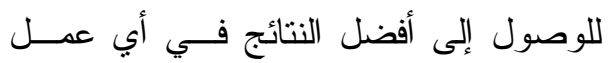

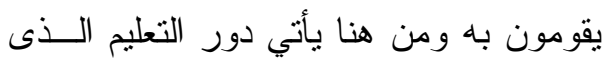
يخر ج طالب لايه ثقة بالنفس، ولديه مستوى دئ دور العطيم أعلى من الطموح، ولديه علاقات اجتماعيـة جيدة مع الآخرين، ولديه دافعية للإنجاز و هذا ما يقوم به التعلم النشط. ومما سبق تتحدد مشكلة البحث في الأســـلة

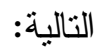
•- هل نوجد فروق بين تلاميذ وتلميذات

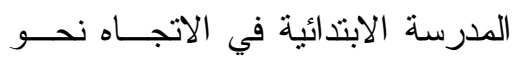
النعلم النشط؟ •- هل توجد علاقة بين الاتجاه نحو التعلم النشط و الدافعية للإنجاز لدى تلاميــذ الداهذ

$$
\text { المدرسة الابتدائية؟ }
$$

• - هل توجد فروق بــين التلاميــذ ذوى الابـ الاتجاه الأعلى و التلاميذ ذوى الاتجـــاه

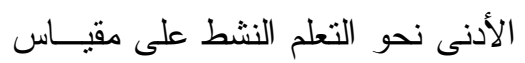
الدافعية للإنجاز؟ تجو أهداف البحث: •. معرفة اتجاه التلاميــذ نحـــو الـتـعلم النشط. •. الكثف عن العلاقة بين اتجاه التلاميذ نحو التعلم النشط ودافعيتهم للإنجاز . 
فعن طريق الاتجاهات يمكن وضع الأفــر اد

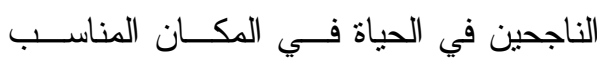
وتصميم البر امج و المناهج الجادة التي نز اعى الاتجاهات، وتعمل على تعزيز الإيجابى منها وتلافى السلبى، وتعد عملية تكوين الاتجاهات

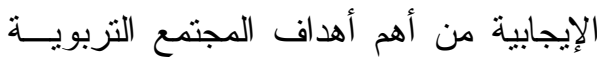
التي يسعى إلى إكسابها لأبنائه.

مفهوم الاتجاه Attitude Concept:

لقد تباينت نظرة الباحثين و المختصين

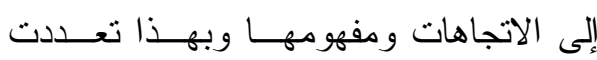
تعريفاتها بحسب الخلفية النظرية النى يـستئد إليها الباحث أو المدرسة التى ينتـــى إليهــا

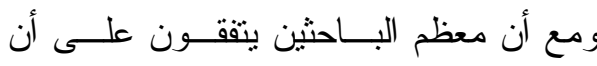
الاتجاه ميل أو استعداد مكتسب يؤدى إلـى لـى لئى

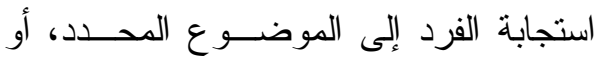
استجابة الفرد إلى الموضوع المحدد استجابة

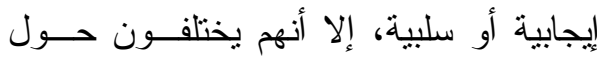

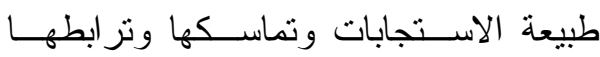

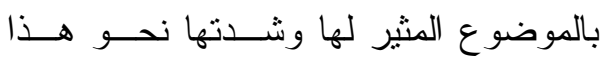

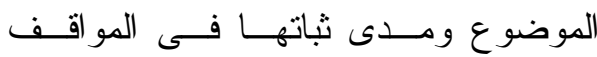

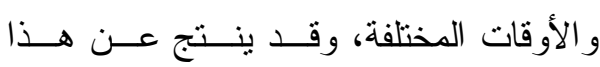
الاختلاف بين البــاحثين ظهــور تعريفـات

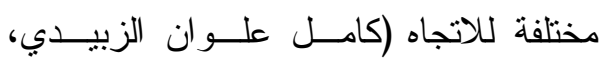
. (1) • . r... r

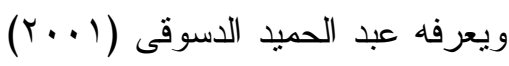

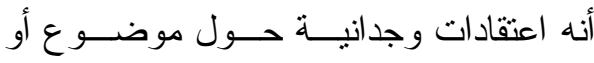
مجموعة مــن الموضـــوعات فــي البيئــة
التلميذ نتيجة مروره بخبر ات سابقة مرتبطـــة بالتعلم النشط ويظهر ذلك في مدى تحمسسه و استمتاعه بطريقة التعلم.

Achievement الدافعيـة للإنجـــاز - .

\section{:motivation}

وتعرف الباحثة الدافعية للإنجاز بأنها:

رغبة التلميذ المستمرة في السعي نحو تحقيق طموحاته في الحياة من خـــلد أداء المهــام

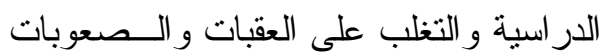
التي تواجهه من أجل الامتياز في الأعمــال

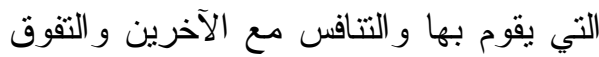

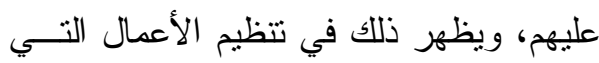
يقوم بها و السرعة في أدائها. الإطار النظري والدراسات السابقة الاتجاه نحو التعلم النشط : • - الاتجاهات النفسية:

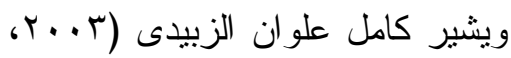

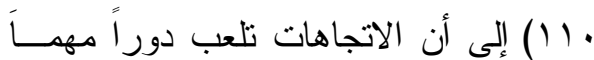
في عملية التعلم، فالطالب الــــى حبـــاه الله

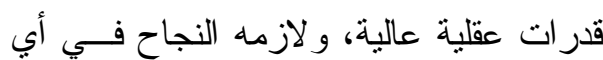
مجال من مجالات الحياة، قد تو اجهه بعـض الصعوبات التعليمية؛ وذللك بـسبب بعـض فض لهـ

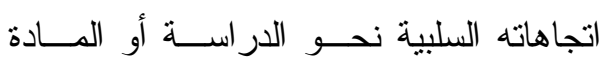

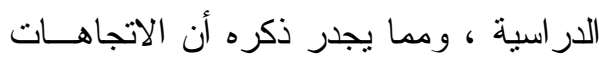
من الموضوعات التي تهم المعلمين وأوليــاء

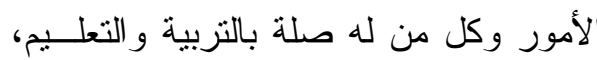


و أكثر ها حداثة ما بسمى بالتعلم القائم علـىى

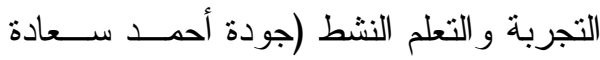

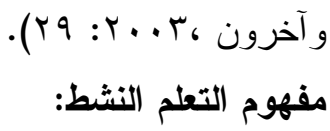

يعتبر مفهوم التعلم النشط من المفاهيم

التربوية الحديثة، و التي تجعل المتعلم محور العمليــــة التعليميــــة بالمقارنــــة بــــالطرق

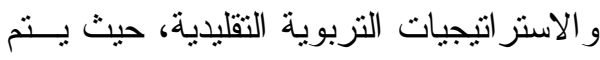
تفعيل دور المتعلم ويجعله يشارك بفعالية في العملية النعليمية.

ويعرفه عبد الهادي عبــــ الله أحمــد

(T7 T. . . V) الطالب مشارك بفاعلية في الموقف التعليمي، من خلال ما يقوم به من بحث وقر اءة وكتابة

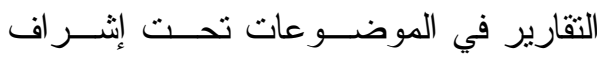
المعلم وتوجيهه.

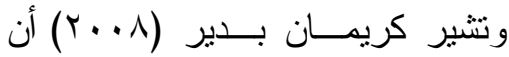
التعلم النشط هو نمط من التشريس يعتمد على

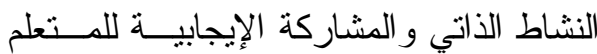

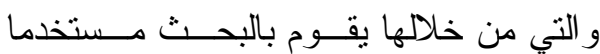

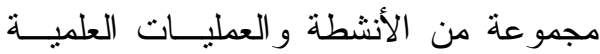
كالملاحظة ووضع الفروض و القياس وقر اءة

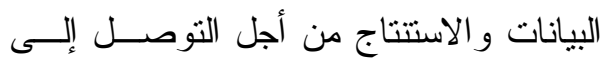

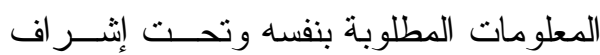
المعلم وتوجيهه وتقويمه.
الاجتماعية وهى متعلمة ونتزع إلى الثبات أو

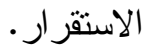
وتعرف سهير كامل أحمـد (1. (Y) الاتجاه بأنه استعداد مكتسب مشبع بالعاطفــة

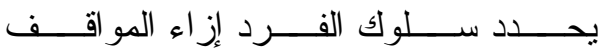
و الموضوعات و الأثخاص التى يتعامل معها فى البيئة المحيطة به إما بقبولها أو رفضها.

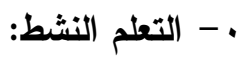

أصــبحت الأســاليب التقليديــة فـي

التثريس لا تلائم الحياة المعاصــرة، ولــــلكـ ظهرت نظريات نربوية عديدة نساعد علـى لـى نـ اكتساب العديــــــــن المهــار ات العقليــة، و الاجتماعية، و الحركية وتتمنل مهمة المعلم الحديث وفقا للطـــرق الحاليــة فـــي إتاحــة الفرصة للمتعلمين لتحصيل المعرفة بأنفسه،

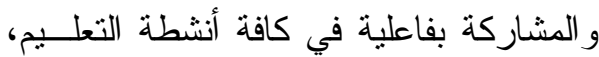
و الإقبال على ذلك برغبة ونشاط حتى يعتادوا

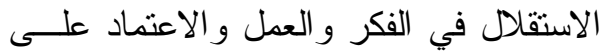
الذات (عقيل محمود رفاعى، Y I . Y V V V).

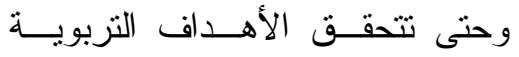

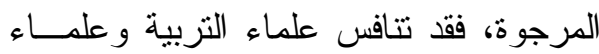
النفس و المرتمون منهم بطرق التعليم و النعلم،

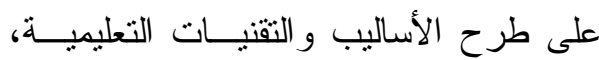
و التي تجعل من المتعلم مفكر ا ناقدا، بعـــ أن الن كان يمثـلـل الـشخص المتلقـي للمعسـارف و الحقائق، وكان من بــين أخــر الأســاليب 
ومر اعاة أن يكون التعلم مرتبط بحياة الثلميذ

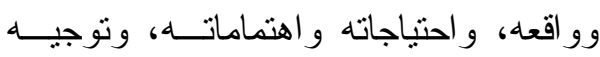

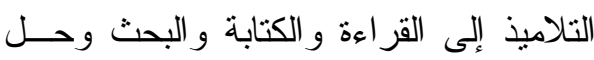

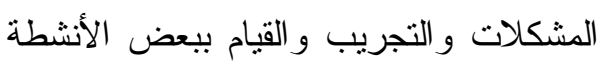
و المهام، ومنح التلاميـذ الفرصـــة لتقــويم

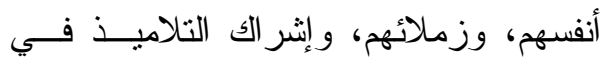

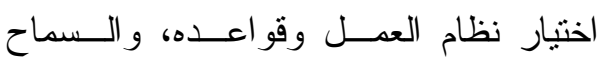
للتناميذ بالتساؤل وطرح الأسئلة على المعلم أو على بعضهم البعض، و إثر الك التلاميذ في تحديد أهدافهم التعليمية، وتوفير بيئة تعليمية مريحة وحرية حركة وجلوس التلاميذ فـي ليني مجموعات صغيرة، ومساعدة المتعلم علـى فهم ذاته و اكتثاف نو احي القـــوة و الــضـف لايه. أهمية التعلم النثط: تتضح أهمية التعلم النشط في النقلـــة

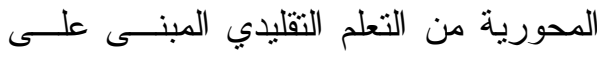
الحفظ والتكر ار إلى التعلم النشط المبنى على مشاركة المتعلم و المعلم على حدا سواء فـــي لفي العملية التعليمية مستخدمين أساليب وطر ائق و استر اتيجيات حديثة تزيد من وتيرة التفاعل

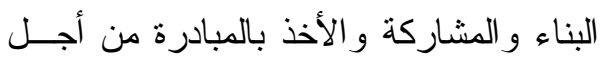

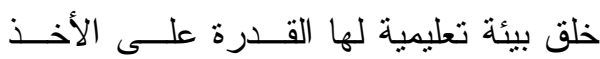
بالمبادئ التعليمية الحديثة في عصر الانفجار

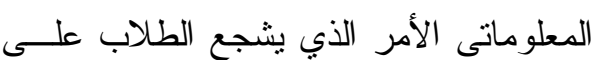

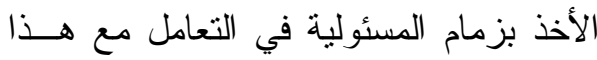

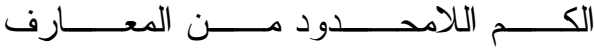

\section{أسس التعلم النشط: - أن}

يعتمد أسلوب الــتعلم النـشط علـى لـى

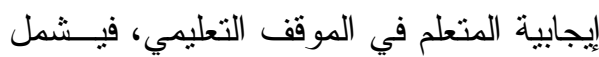

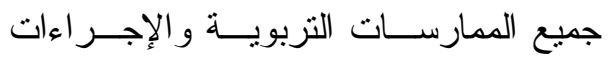
التذريسية التي تهدف إلى تفعيل دور المتعلم

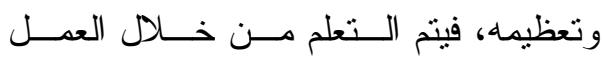
و التجريب، و اعتماد المتعلم على ذاتــه فــي الحصول على المعلومات و اكتساب المهار ات

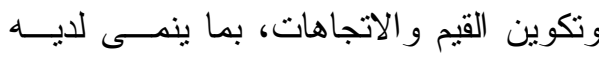

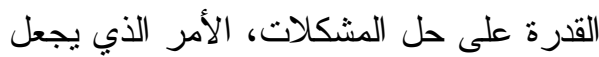

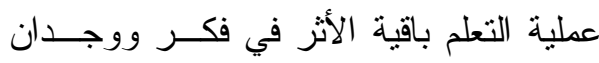
التلميذ. ويتفق كـلـ مــن (عقـــل محمــود

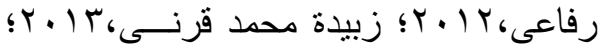

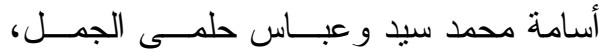

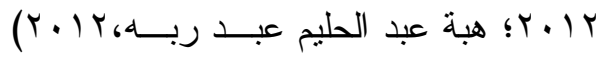
على أن التعلم النشط يشجع المشاركة النشطة

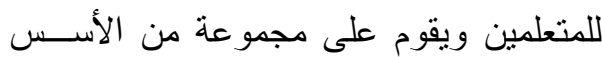

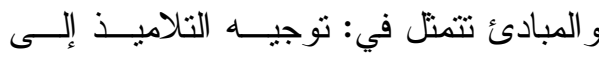
مصادر المعرفة و التعلم وتتوعهــا، و إتاحسـة فرصة التعلم الذاتي للتلاميذ، و إثناعة جو من ولن

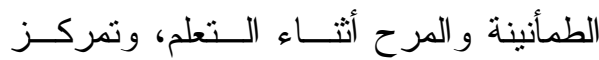

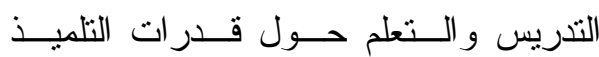
و إمكانياته، وتدريب المتعلمين علــى الإدارة

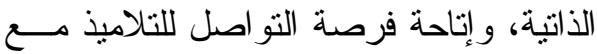
بعضهم ومع المعلم، ومر اعاة الفروق الفردية

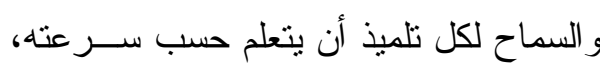


- يساعد في إيجاد تفاعـل إيجـابي بــين

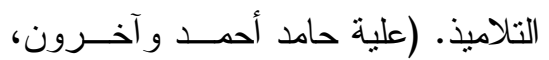

( $r$. . o

- يساعد التعلم النشط على تغيير صــورة المعلم بأنه المصدر الوحيد للمعرفة وهذا تلئل دلالة تضمين هام للنمو المعرفى المتعلق

$$
\text { بفهم طبيعة الحقيقة. }
$$

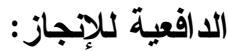

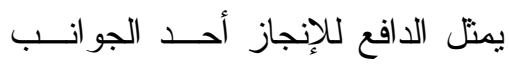

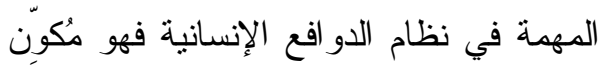

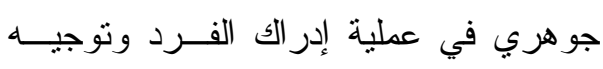
سلوكه، وتحقيق ذاته من خلال ما ينجزه من في إن

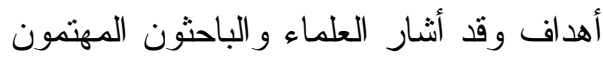

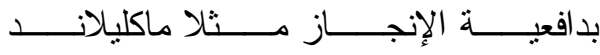
McClelland

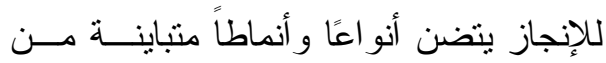
السلوك، حيث تعمل أو تؤثر دافعية الإنجــاز

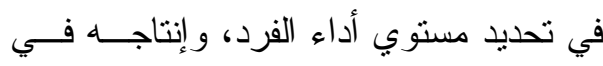
مختلف المجالات، والأنشطة التي يو اجههــا،

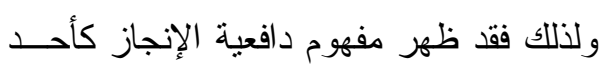
المعالم المميزة للار اسة و البحث في ديناميات الشخصية و السلوك، وذللك منذ ستينات القرن

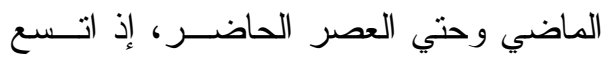
الاهتمام به ليشمل در اسة علاقته بمتغيــرات

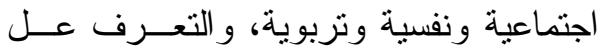
العو امل التي تسه في تفسر التباين في دافعية

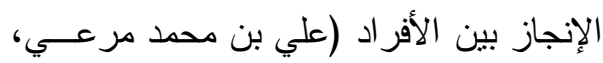

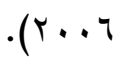

و المعلومات(أسامة محمد سيد وعباس حلمى

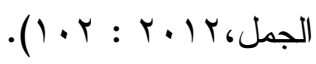

\section{ويمكن تحديد أهمية التعلم النشط فيما يلي:} - يزيد من اندماج التلميذ في العمل. - يجعل من التعلم متعة وبهجة.

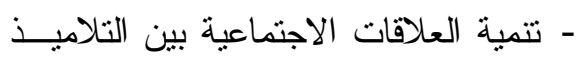
وبعضهم البعض وبين المعلم.

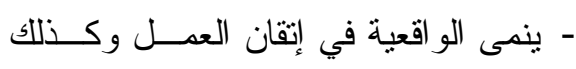
يعمق النقة بالنفس و التعبير عن الـــرأي.

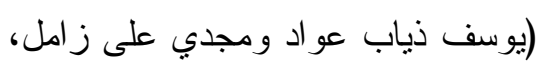
( $r \cdots q$ - يعتبر مجال للكثف عن ميول المتعلمين و إثباع حاجاتهم.

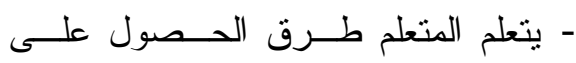

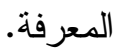
- يهتم باستثارة المعارف السابقة، ويعتبـــر ذلك شرط ضروري لحدوث التعلم وهذا يتفق مع مبادئ نظريات التعلم الحـــيث

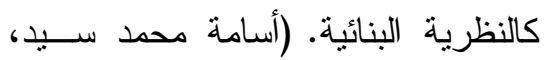

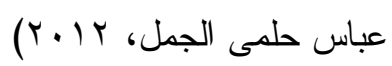
- يعزز التتافس الإيجابي بين التلاميذ.

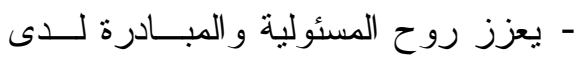

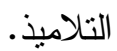
- يحفز التلاميذ على كثرة الإنتاج وتتو عه. - ينمى القدرة على التفكير و البحث. - يعود التلاميذ على اتباع قو اعد العهـلـل وينمى لديهم اتجاهات وقيم إيجابية. 
للوصول إلى الامنياز في أداء الأعمال

$$
\text { التي يقوم بها. }
$$

•- التنظيم والدقة: حرص التلميذ علـى التهى

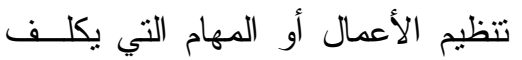

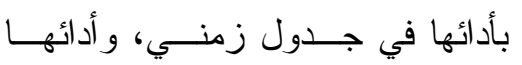

$$
\text { بسر عة ودقة. }
$$

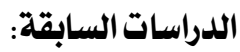

دراسات اهتمت بــالتعلم النـشطط وعلاقتــهـه

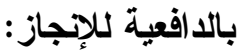

هدفت دراسة علي حسانين(999 199)

إلي معرفة فعالية استخدام الـتـعلم التعسـاوني و التعلم الفردي كأحد اســـنز اتيجيات الــتعلم النشط في تدريس الرياضيات علــي تتميــة التقكير الابتكاري و الدافع للإنجاز لدي تلاميذ الديات

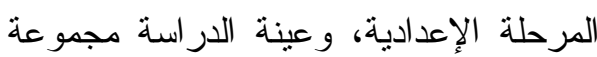

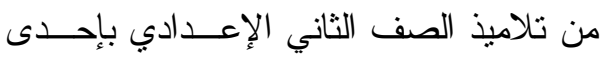

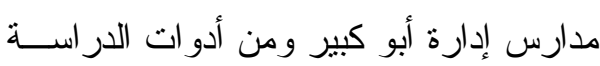

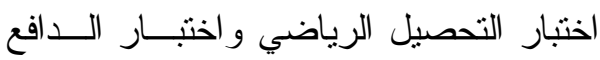

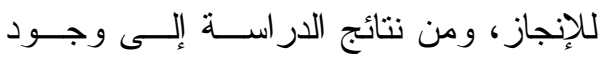

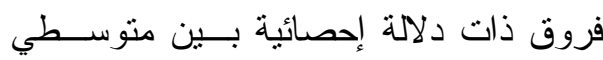

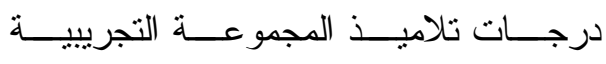
و المجموعة الضابطة في الاختبار التحصيلي لصالح المجموعة التجريبية، ووجود فــروق ذات دلالة إحصائية بين متوسطي درجـات

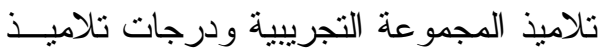
المجموعة الضابطة فــي اختبـــار الدافعيــة للإنجاز لصالح المجموعة التجريبية.

\section{مفهوم الدافعية للإججاز :}

تمنل الدافعية للإنجاز أحد الجوانــب

المهمة في نظام الدو افع الإنسانية، وقد برزت لهدارت

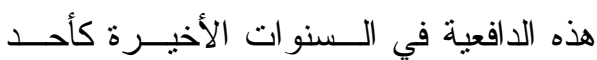

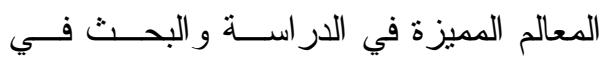
ديناميات الثخصية و السلوك، بــل ويمكـنـ اعتبار فاعلية الإنجاز واحدة مــن منجـزات ولـات الفكر السيكولوجي المعاصر (رامــي الـسيد

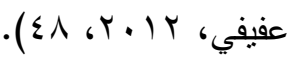
أبعاد الدافعية للإنجاز : أل

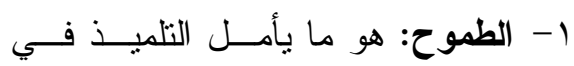

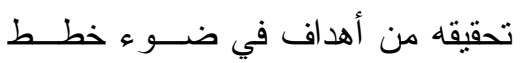
يسعى للقيام بها وتتفيذها. r- المثابرة: حماس التلميذ لأداء ما يكلف

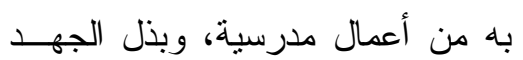
للتغلب على العقبات التي نو اجهه فــي وني

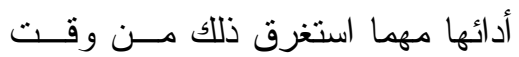

$$
\text { وجهذ بغرض النجاح }
$$

r- المنافسة: اهتمام التلميذ بإظهار أفضل أداء لايه، وسعيه للتفوق على زملائه

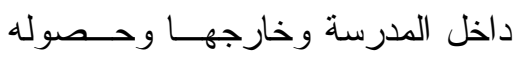
على أعلى مرتبة يمكن الوصول إليها. ع- السعي نحو التميز : رغبة التلميذ فـي

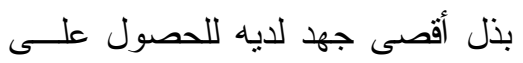
أعلى الدرجات في در اســته، وعمــل الأشياء التي يكلف بها بكفاءة و إتقــان 
للإنجاز (إعداد البــاحثنين)، ومقيــاس الثقـــة

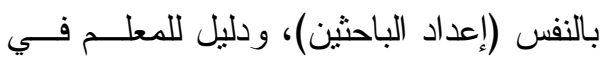
استخدام استر اتيجيات التعلم النـشط (إعـــداد

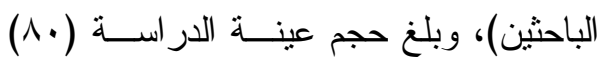

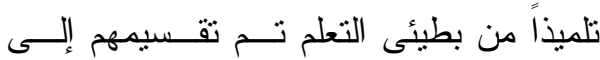
مجمو عتين: تجريبية وضابطة بلغ حجم كـلـل

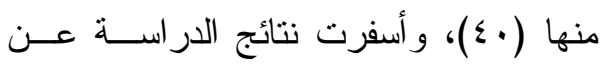

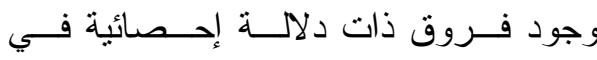

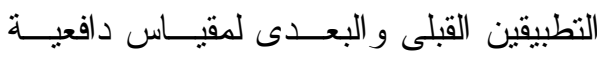
الإنجاز ولصالح النطبيق البعدى، كما وجدت فروق دالــة بــين المجمــوعتين الــضـابطة والتجريبية في مقياس دافعية الإنجاز لصالح المجمو عة التجريبية. و لاحظت الباحثــة فــي الدراســات

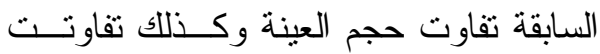

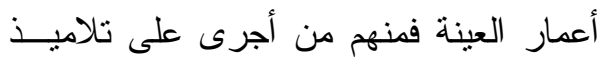

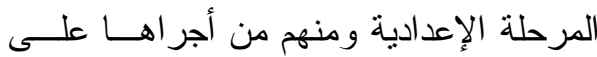
المرحلة الثانوية ومنهم بطيئ التعلم ومــنهم ذوى صعوبات التعلم ومن الدراسات الـسابقة يتـضـح أن استر اتيجيات التعلم النـشطط مــع اختلافهـــا

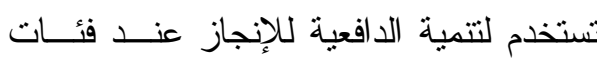

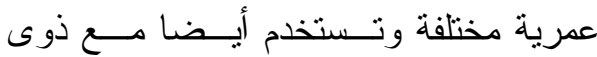
الاحتياجات الخاصة كما في در اســـة ناديــة

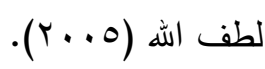

بينما هدفت دراسة نادية لطــف الله

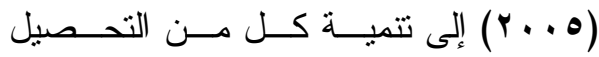
و التقكير الابتكاري وزيادة الدافعية للإنجــاز

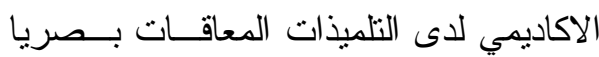
بمدارس النور و الأمل باستخدام استر اتيجية " فكر -ز اوج سشارك " كإحدى اســتر اتيجيات التعلم النشط في تعليم العلوم التي تتاسب فئة المعاقين بصريا و الاسترشاد بها في اختيــار

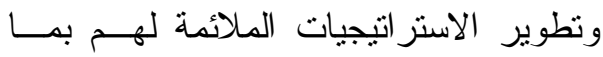
يمكن المعلمين من التفاعل الجيد مــع هــــه الفئة لتحقيق أهداف التزبية العلمية، وكـــان محتوى التعلم هو وحدتي (الحيوان في بيئتنا، الإنسان و الكون) المقرر در استهما في كتاب

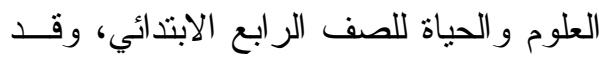

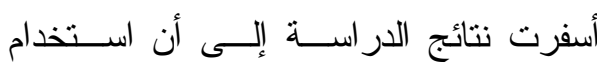

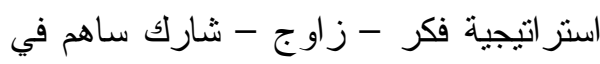
زيادة مستوى التحصيل الدر اسي فـي مـــادة العلوم و التفكير الابتكاري ودافعية الإنجــاز

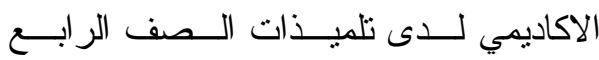

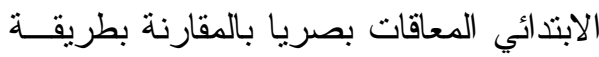
المحاضرة التقليدية .

كما هدفت دراســة ياســرة أيــوب

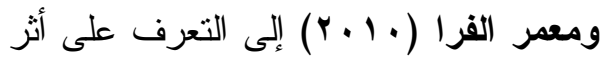

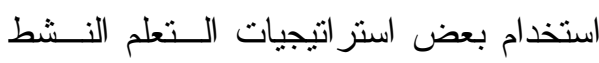
على دافعية الإنجاز و الثقة بالنفس و التحصيل الدر اسى لدى التلاميذ بطيئى التعلم؛ واستخدم الباحثنان ثناثة أدوات هي مقيــاس الدافعيــة 


$$
\begin{aligned}
& \text { الفصل الدراسـي الأول مــن العـام }
\end{aligned}
$$

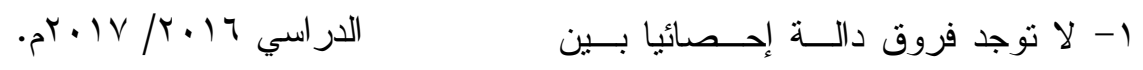

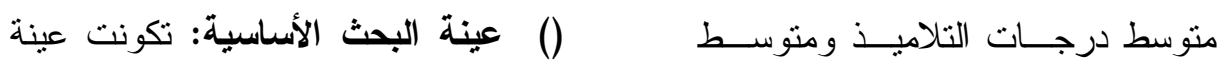

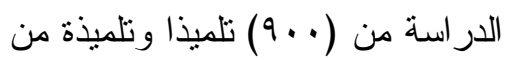

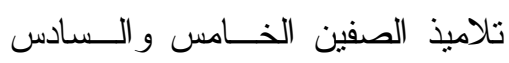

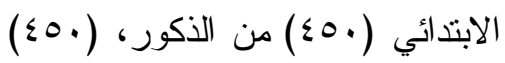

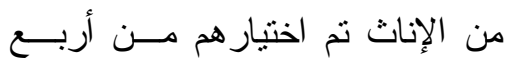

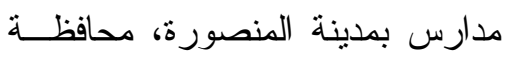

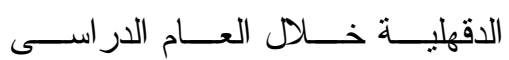

$$
\begin{aligned}
& \cdot(r \cdot 1 \Lambda / r \cdot \mid r)
\end{aligned}
$$

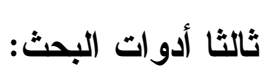

$$
\begin{aligned}
& \text { •- مقياس الاتجاه نحو التعلم النشط إعــداد } \\
& \text { الباحثة. } \\
& \text { مقياس الدافعية للإنجاز إعداد الباحثة. } \\
& \text { الخصائص السيكومترية لمقيــاس الاتجــاه } \\
& \text { نحو التعلم النشط: } \\
& \text { أولا: صدق المقياس: } \\
& \text { • - - صدق المحكمين: } \\
& \text { قامت الباحثة بعرض المقيــاس فـي } \\
& \text { صورته الأولية علي مجموعة من المحكمين } \\
& \text { بلغ عددهم (11) محكماً من المتخصــصين } \\
& \text { في علم النفس التزبوي و الــصحة النفـسية } \\
& \text { للحكم علي المقياس من حيث: } \\
& \text { • مدى وضوح الصياغة اللغوية للعبارات } \\
& \text { ومناسبتها لتلاميــذ الــصف الخــامس } \\
& \text { و السادس الابتدائي. } \\
& \text { درجات التلميذات في المدرسة الابتدائية } \\
& \text { على مقياس الاتجاه نحو التعلم النشط. } \\
& \text { r- يوجد معامل ارتباط دال إحصائيا بــين } \\
& \text { درجات تلاميذ المدرسة الابتدائية على لئي }
\end{aligned}
$$

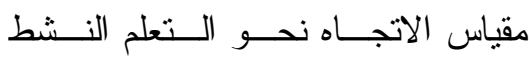

$$
\begin{aligned}
& \text { ودرجاتهم على مقياس الدافعية للإنجاز • }
\end{aligned}
$$

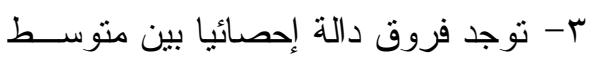

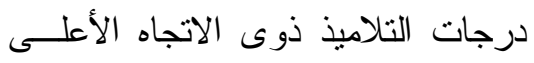

$$
\begin{aligned}
& \text { نحو التعلم النشط ومتوســـ درجــات } \\
& \text { التلاميذ ذوى الاتجاه الأدنى نحو التعلم } \\
& \text { النشط على مقياس الدافعيــة للإنجــــاز }
\end{aligned}
$$

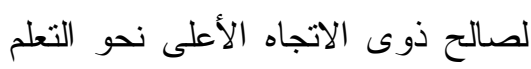

$$
\begin{aligned}
& \text { النشط. }
\end{aligned}
$$

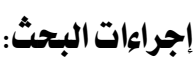

$$
\begin{aligned}
& \text { أولا منهج البحث: استخدمت الباحثة المنهج } \\
& \text { الارنباطي المقارن. } \\
& \text { ثانيا عينة الار اسة: }
\end{aligned}
$$

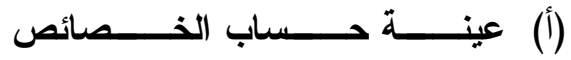

$$
\begin{aligned}
& \text { السيكومترية: تم تطبيق أدوات البحث }
\end{aligned}
$$

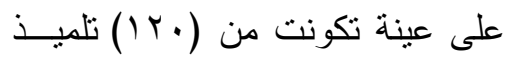

$$
\begin{aligned}
& \text { وتلميذة من تلاميذ الصف الخــامس }
\end{aligned}
$$

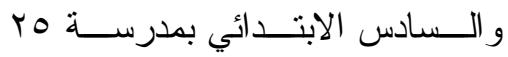

$$
\begin{aligned}
& \text { يناير، التابعة لإدارة غرب المنصورة }
\end{aligned}
$$

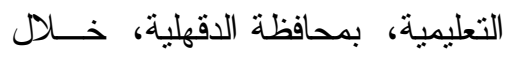


9 . . ب؛ آمال سعد سيد، 10 • ب) لذلك لجأت الباحثة إلى استخدام درجات التحصيل للتحقق

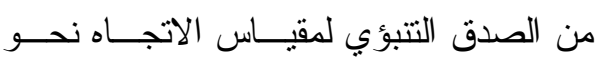
التعلم النشط.

حيث قامت الباحثة بحساب الــصدق

النتبؤي من خلال نطبيق مقياس الاتجاه نحو

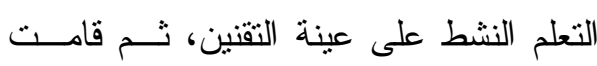
بحساب معامل الارتباط بين درجات التلاميذ

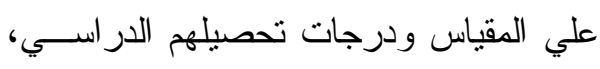
وقد بلغت قيمة معامل الارتبـاط (ال7؛، •)

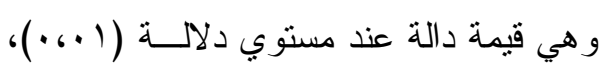

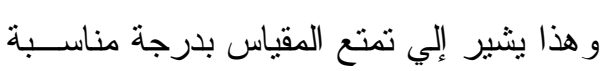
من الصدق. ثانيا: ثبات المقياس:

\section{ا-طريقة ألفا كرونباخ:}

قامت الباحثة بحساب معامـلـل ألفــــا

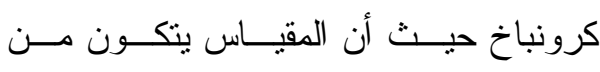
عبار ات وليس أبعاد، كما هو موضح بجدول

:(1)
• مدى ارتباط العبارة بالتعريف الإجرائي.

• مدي مناسبة البدائل للعبار ات: (غالبـاً،

أحياناً، نادر اً).

• حذف أو تعديل أو إضافة أي مقترحات

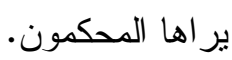

ثم قامــت الباحثــة بـإجر اء كافــة

التعــديلات وفـتق آر اء الـسـادة المحكمــين

وملاحظاتهم، و التــي تمنلـــت فــي إعـادة الصياغة اللغوية لبعض العبار ات، وقد أثنار المحكمون إلي مناسبة عبار ات المقياس، وقد لفيدانه

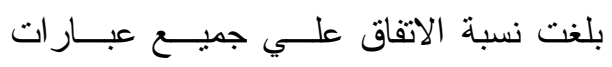

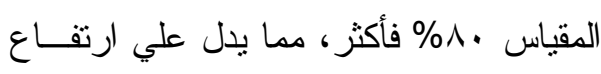

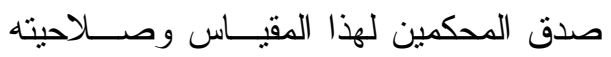
للنطبيق. • - الصدق التنبؤي:

أنشارت نتائج العديد مــن الدراست اســات إلى وجود علاقة دالة بين درجات التحصيل

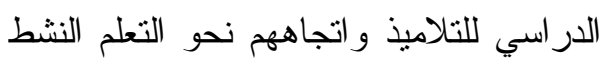
منها در اسةة: (فاطمة محمد عبــــ الوهـــاب،

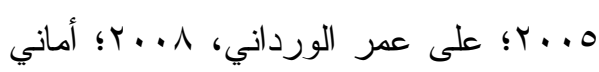
سيد فرغلي، 9 . . r؛ نجاة حسـن شـــاهين، 
جدول (1)

قيم معاملات ثبات مقياس الاتجاه نحو التعلم النثط (العبارات والارجة الكلية) بحساب معامل ألفا كرونباخ

\begin{tabular}{|c|c|c|c|c|c|}
\hline مستوي الدلالة & معامل ألفا كرونباخ & رقم العبارة & مستوي الدلالة & كرونباخ & رقم العبارة \\
\hline$\cdot 61$ & - ،AMr & 11 & $\cdots 1$ & • ،А & 1 \\
\hline .61 & • ‘АYA & 19 & $\cdot 61$ & 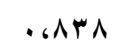 & r \\
\hline .61 & • ‘AYV & r. & $\cdots 1$ & • ‘ & $r$ \\
\hline .61 & . ‘AYV & r & $\cdot 6 \cdot 1$ & . ‘ATs & $\varepsilon$ \\
\hline$\cdot 61$ & . ‘А $q$ & rr & .61 & • ‘ATO & - \\
\hline .61 & . ‘یr. & $r r$ & .61 & • ، & 7 \\
\hline$\cdot 61$ & • • & $r \varepsilon$ & $\cdots 1$ & • ‘АTs & $v$ \\
\hline$\cdot 6 \cdot 1$ & . ‘АY & ro & $\cdots 1$ & . ‘А $৭$ & $\wedge$ \\
\hline$\cdot 6+1$ & . ،ATr & rq & $\cdots 1$ & . ‘А & 9 \\
\hline$\cdot 6+1$ & • ،Arv & rV & $\cdots 1$ & . ‘ & 1. \\
\hline .61 & • ‘Аr. & rᄉ & $\cdots 1$ & ו ו • & 11 \\
\hline$\cdot 6 \cdot 1$ & • • & rq & .61 & . ،Ar. & ir \\
\hline$\cdots 1$ & . ‘АYA & r. & $\cdots 1$ & . ‘AMr & Ir \\
\hline$\cdots 1$ & . ‘ $A Y q$ & r & $\ldots 1$ & . ، & $1 \leq$ \\
\hline 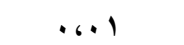 & • • • & rr & $\ldots 1$ & •،八ץ. & 10 \\
\hline$\cdots 1$ & • • & r & $\cdots 1$ & . ‘ & 17 \\
\hline .61 & . ‘ AYY & $r \varepsilon$ & $.6+1$ & ع & 18 \\
\hline & & & $.6+1$ & • ، & الارجة الكلية \\
\hline
\end{tabular}

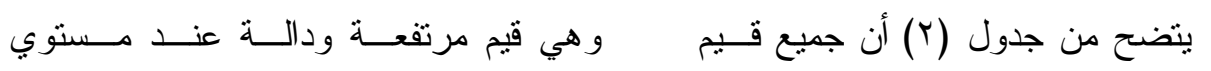

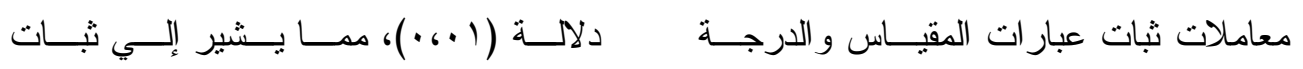

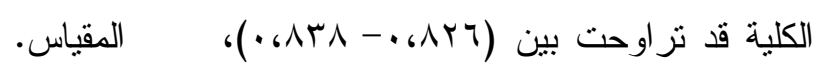


ثالثا: الآساق الا(خلي للمقياس:

لحساب الاتــساق الــــاخلي لمقيــاس

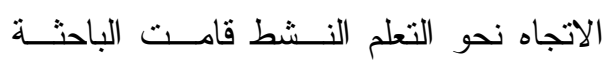
بتطبيق المقياس علي عينة التقنين، وحسـساب

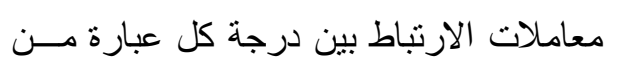

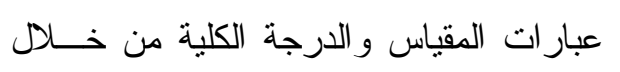

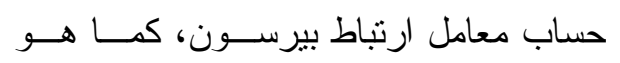

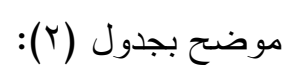

r -طريقة اعاده التطبيق: قامت الباحثة بــالتحقق مــن ثبـــات

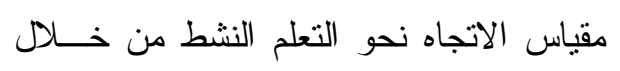

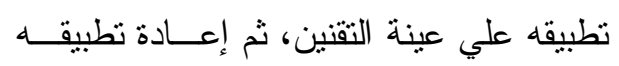
على العينة نفسها بفاصل زمني أسـبو عين،

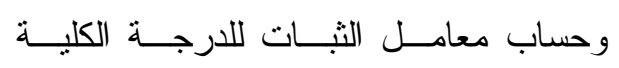
للمقياس، وقد بلغت قيمته (VVI، و •) وهـي

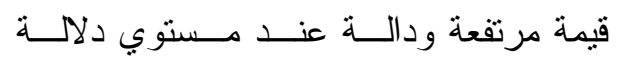

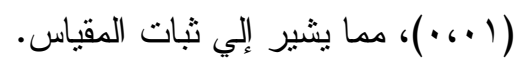

جدول (r)

قيم معاملات الارتباط بين درجة كل عبارة والارجة الكلية لمقياس الاتجاه نحو التعلم النشط

\begin{tabular}{|c|c|c|c|c|c|c|c|c|}
\hline مستوي & معامل الارتباط & رقبارة & الدلاية & معامل الارتباط & راقم & مستوي الدلالة & معامل الارتباط & رقام \\
\hline .6 .1 & r & ro & .61 & . ، & ir & .61 & . & 1 \\
\hline$\cdots+1$ & ט, r. & Y &..+1 & • & $1 \leqslant$ &.. .0 & . & $r$ \\
\hline .60 & . G T. T & rV &..+1 & $.0 \leqslant \leqslant r$ & 10 & $\cdots 1$ & ומrם. & $r$ \\
\hline$\cdot 6+1$ & . $، \leqslant Y \wedge$ & rA &..+1 & ع سه، . & 17 & $\cdots 1$ & ווד،. & $\varepsilon$ \\
\hline .61 & . GYAV & rq & .61 & rq"r. & IV & $\ldots 1$ & . (rq1 & 0 \\
\hline .61 & $\cdot ، \leqslant \wedge \vee$ & r. & $\cdot 6 \cdot 1$ & . r rAr & 11 & $\cdots 1$ & rוr، & 7 \\
\hline .6 .1 & . & r & $\cdots$ & $. \quad 6 \leqslant 9$. & 19 & $\cdots 1$ & מ & $v$ \\
\hline .6 .1 & . ، $\leqslant 11$ & rr & $\cdots$ & . ،OY. & $r$. & $\ldots 1$ & . $6 \leqslant V q$ & $\Lambda$ \\
\hline .6 .1 & . . & rr & $\cdots$ & .000 & rI &. .61 & . $، \leqslant V 1$ & 9 \\
\hline \multirow[t]{3}{*}{$\cdots$} & . orv & & .61 & . $6 \leq \leqslant 7$ & rr &..+1 & צ דו6. & 1. \\
\hline & & & $\cdots$ & ד & $r r$ & $\cdots 1$ & r & 11 \\
\hline & & & $\cdots$ & . & $r \leq$ & $\cdots 1$ & . $، \leqslant V V$ & Ir \\
\hline
\end{tabular}


ثم قامــت الباحثــة بـإجر اء كافــة

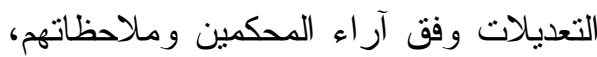

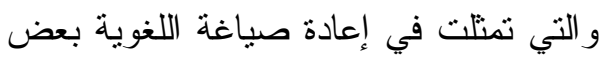

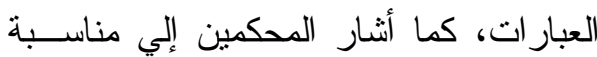

عبار ات المقياس، وقد بلغت نـسبة الاتفــاق

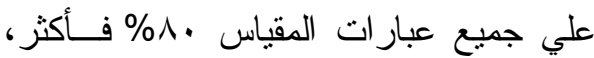
مما يدل علي ارتفاع صدق المحكمين لهـــا المقياس وصلاحيته للنطبيق.

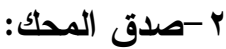

لحساب صدق المحك قامت الباحثــة

بتطبيق مقياس الدافعية للإنجاز علــي عينــة التقنين، وتطبيق مقيــاس الــــافع للإنجـــاز

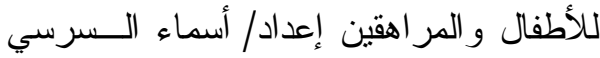

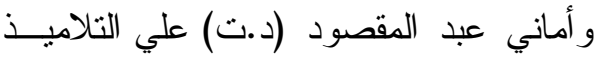
أنفسهر، ثم قامت بحساب معامل الارتباط بين

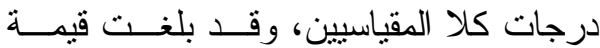

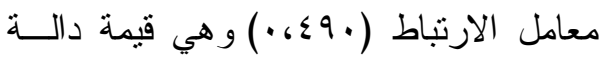
عند مستوي دلالة (1 (،، •)، مما يشير إلـي تمتع المقياس بدرجة مناسبة من الصدق. ثانيا: ثبات المقياس: 1-طريقة ألفا كرونباخ:

قامت الباحثة بتطبيق المقياس علـي عينة الثقنين، ثم حساب معساملات الثبــات

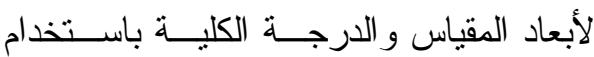

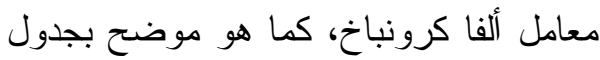

$:(r)$
يتضح من جدول (r) أن جميع قـيم

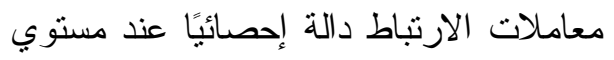

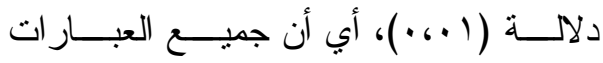

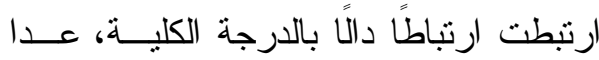

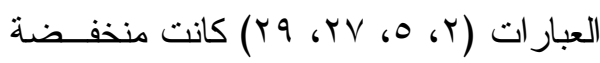
وتم حذفها، مما يشير إلـي تمتــع المقيــاس

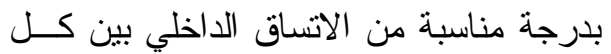

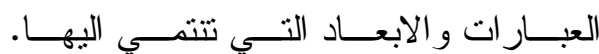
الخصائص السيكومترية لمقياس الدافعيـة

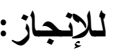
أولا: صدق المقياس: 1 إلصدق المحكمين:

قامت الباحثة بعرض المقيــاس فــي

صورته الأولية علي مجموعة من المحكمين

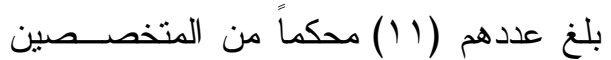
في علم النفس التربوي و الــصحة النفـسية للحكم علي المقياس من حيث:

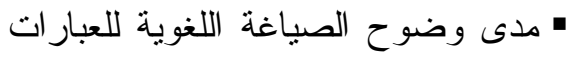

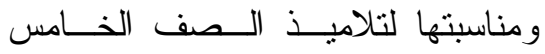
و السادس الابتدائي. • مدى ارتباط العبارة بالتعريف الإجر ائي

$$
\text { للبعد الذي تتدرج تحته. }
$$
• مدي مناسبة البدائل للعبار ات: (غالبـاً، (أحياناً، نادر اً). • حذف أو تعديل أو إضافة أي مقترحات نات

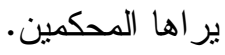


جدول (r) قيم معاملات ثبات مقياس الدافعية للإنجاز (الابعاد والارجة الكلية)

باستخدام معامل ألفا كرونباخ

\begin{tabular}{|c|c|c|}
\hline مستوي اللالالة & معامل ألفا كرونباخ & الابعاد - ل الاد \\
\hline..+1 &. . $A 9 \mathrm{r}$ & الطموح \\
\hline 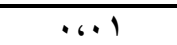 &. . 1997 & المثابرة \\
\hline..+1 &. .914 & المنافسة \\
\hline. .1 & 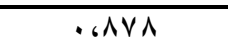 & السعى نحو التميز \\
\hline.. .1 & $\cdot . \wedge \wedge \wedge 0$ & التنظيم والدقة \\
\hline.,.+1 & .6914 & الارجة الكلية \\
\hline
\end{tabular}

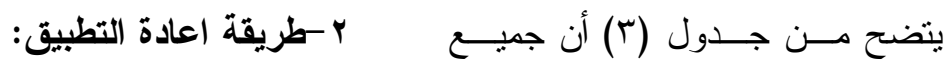

قيم معاملات الثبات لأبعاد المقياس و الدرجة

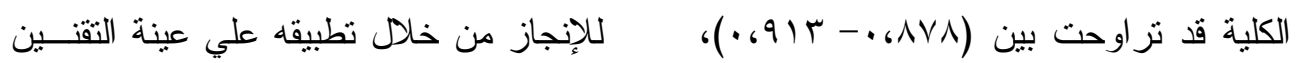

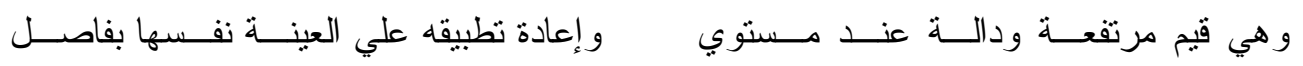

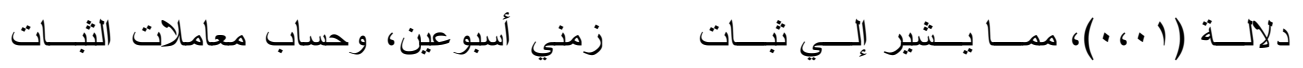

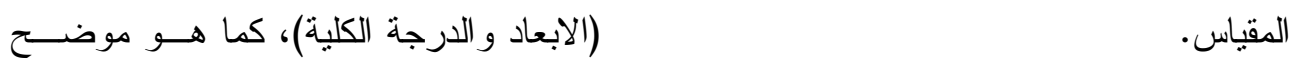

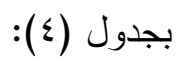

جدول (ء) قيم معاملات ثبات مقياس الا (فعية للإنجاز (الابعاد والدرجة الكلية)

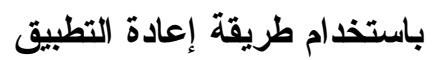

\begin{tabular}{|c|c|c|}
\hline مستوي الدلاةة & معامل الثبات & الابعاد \\
\hline .61 & . $V \vee V \mu$ & الطموح \\
\hline$\cdot 6+1$ & .67 .9 & المثابرة \\
\hline .61 & .6794 & المنافسة \\
\hline .6 .1 & $.679 V$ & السعى نحو التميز \\
\hline $.6 \cdot 1$ & .6271 & التنظيم والدقة \\
\hline$\cdots 1$ & • • & الارجة الكلية \\
\hline
\end{tabular}

1- حساب معاملات الارتباط بين درجة

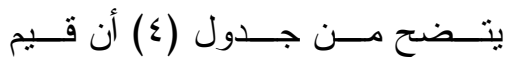

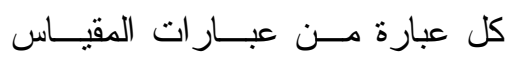
و الدرجة الكلية للبعد الذي تتنمي إليه

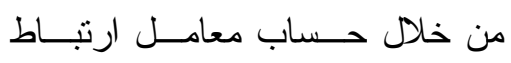

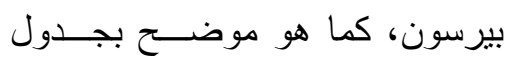

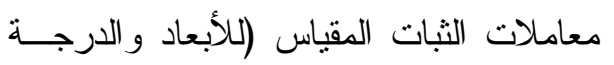
الكلية) جميعها قيم مرتفعة ودالة عند مستوي دلالة (1 •، •)، مما يشير إلي ثبات المقياس.

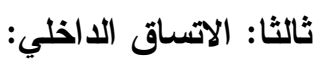

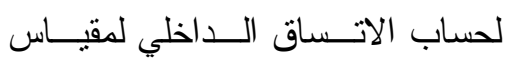

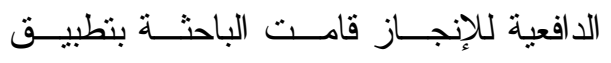

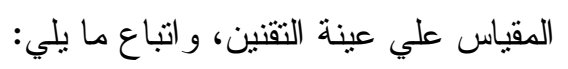


جدول (0) قيم معاملات الارتباط بين درجة كل عبارة والدرجة الكلية

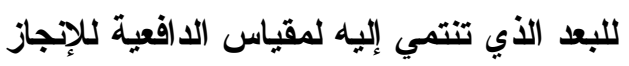

\begin{tabular}{|c|c|c|c|c|c|c|c|c|}
\hline \multicolumn{3}{|c|}{ المنافسة } & \multicolumn{3}{|c|}{ المثابرة } & \multicolumn{3}{|c|}{ الطموح } \\
\hline مستوي الالالة & معامل الارتباط & العبارة & مستوية الدلاي & معامل الارتباط & العبارة & الالالةً & معامل الارتباط & العبارة \\
\hline .6 .1 & $.6 \leqslant 7 \Lambda$ & 1 & $.6+1$ & . ، $\leqslant 0 r$ & 1 & .6 .1 & .6570 & 1 \\
\hline $.6+1$ & $.6 \$ 99$ & $r$ & .61 &..$\varepsilon V Y$ & $r$ &. .1 & $.67 \leq \varepsilon$ & $r$ \\
\hline .6 .1 &. $.0 \wedge V$ & $r$ & .61 & .0010 & $r$ & .61 & $.60 \leqslant$. & $r$ \\
\hline .6 .1 & $.601 \leq$ & $\varepsilon$ &..$\cdot 1$ & $.6 \mathrm{rqV}$ & $\varepsilon$ & .6 .1 & $.60 Y \varepsilon$ & $\varepsilon$ \\
\hline .61 & $.6 \leqslant 17$ & 0 & .61 & $.6 \mathrm{rAl}$ & 0 &. .1 & $.00 Y 1$ & 0 \\
\hline .6 .1 & $.60 Y \mu$ & 7 &. .1 & $.00 \leq \leqslant$ & 7 & .6 .1 & $.00 \leqslant 1$ & 7 \\
\hline .61 & .604. & $\mathrm{v}$ & .61 & $.00 V \mu$ & $\mathrm{V}$ & .6 .1 & $.60 . r$ & 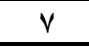 \\
\hline .6 .1 & $.60 \mathrm{Vr}$ & $\Lambda$ & .61 & .60 .9 & $\Lambda$ & .61 & .6049 & $\Lambda$ \\
\hline \multirow[t]{15}{*}{.6 .1} & $.6 \varepsilon \cdot 1$ & 9 &. .1 &. $.07 \mathrm{~V}$ & 9 & .61 & $.6 \leqslant 91$ & 9 \\
\hline & .6047 & 1. & & & & .61 & $.60 Y r$ & 1. \\
\hline & & & & & &. .1 & .6711 & 11 \\
\hline & & & \multicolumn{3}{|c|}{ التنظيم والدقة } & \multicolumn{3}{|c|}{ السعى نحو التميز } \\
\hline & & & مستوية الدالية & الارتباط & العبارة & الدستوية & الارتباط & العبارة \\
\hline & & & .61 & $.00 \%$ & 1 & .61 &. . YAr & 1 \\
\hline & & & .61 & $.64 \leq 8$ & $r$ &..+1 & .6000 & $r$ \\
\hline & & &. .1 &. $.0 \mathrm{VV}$ & $r$ & .61 & $. \quad 6 \leqslant \leqslant V$ & $r$ \\
\hline & & &. .1 & $.00 \mathrm{r}$ & $\varepsilon$ & $\ldots+1$ & .6710 & $\varepsilon$ \\
\hline & & & .61 & 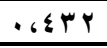 & 0 &. .1 & .67 .4 & 0 \\
\hline & & &. .11 & $.00 \mathrm{~V}$ & 7 &. .1 & .6791 & 7 \\
\hline & & & .61 & .6707 & $v$ & .61 & .6509 & V \\
\hline & & &. .11 & .6790 & $\Lambda$ & $.6+1$ & $.00 \vee 0$ & $\Lambda$ \\
\hline & & & & & & .61 & $.67 \mathrm{~V}$ & 9 \\
\hline & & & & & & .6 .1 & ודים. & 1. \\
\hline
\end{tabular}

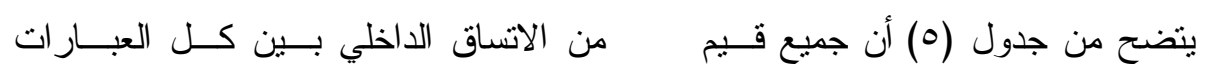

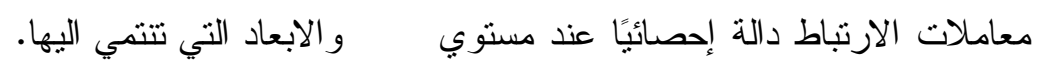

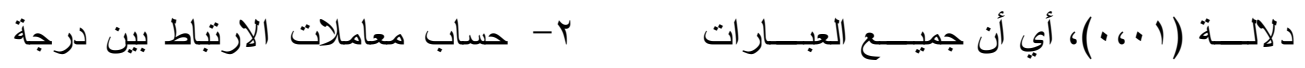

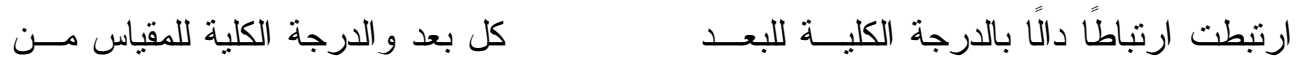

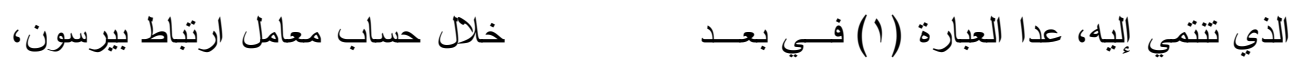

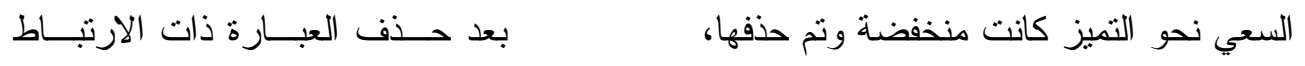

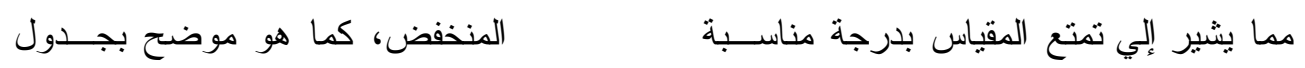

$:(7)$ 


\section{جدول (7)}

قيم معاملات الارتباط بين درجة كل بعد والارجة الكلية لمقياس الافعية للإججاز

\begin{tabular}{|c|c|c|}
\hline مستوي الدلالة & الارجة الكلية & الابعاد \\
\hline$\cdot 6.1$ & . ‘А^ & الطموح \\
\hline$\cdot 6.1$ & $\cdot ، \wedge \bullet \wedge$ & المثابرة \\
\hline $.6+1$ & $\cdot ، \Lambda \cdot r$ & المنافسة \\
\hline$\cdots+1$ & .69 .9 & السعى نحو التميز \\
\hline $.6+1$ & . ‘Аᄉ & التنظيم و الدقة \\
\hline
\end{tabular}

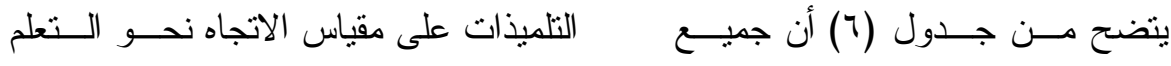

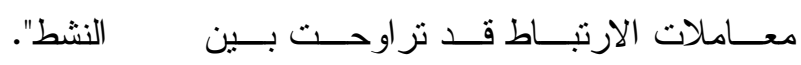

وللتحقق من هذا الفرض اســتخدت

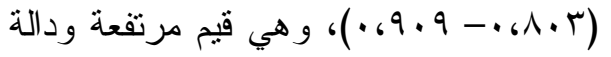

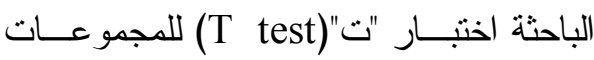

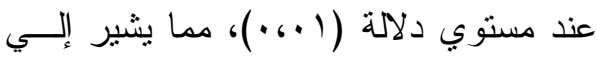

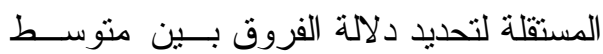

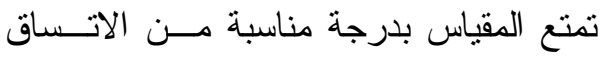

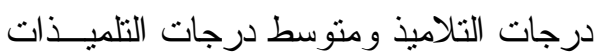
في المدرسة الابتدائية على مقيــاس الاتجـــاه نتائن البحث وتفسيرها

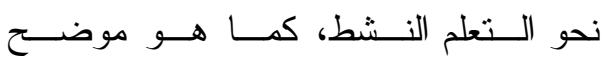
نتائج الفرض الأول

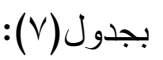
ينص الفرض الأول على: - تلى الاول

$$
\begin{aligned}
& \text { "لا توجد فروق دالة إحــصائياً بــين }
\end{aligned}
$$

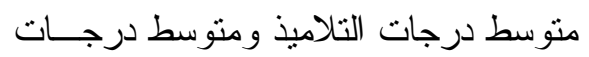

\section{جدول (v)}

قيمة " ت " ودلالتها الإحصائية للفروق بين متوسط درجات التلاميذ ومتوسط درجات التلميذات

\begin{tabular}{|c|c|c|c|c|c|c|c|}
\hline مستوى & الررية & قيمة (ت) & الاحعراف & المتوسط & ن & النوع & \multirow{3}{*}{ نحو التعلم النشط } \\
\hline \multirow{2}{*}{$\cdot,+1$} & \multirow{2}{*}{ VVr } & \multirow{2}{*}{ r, rqr } & $\Lambda, T \vee r$ & $V r, \wedge V$ & rVT & ذكر & \\
\hline & & & $v, v \vee I$ & V & $\varepsilon \cdot r$ & انثى & \\
\hline
\end{tabular}

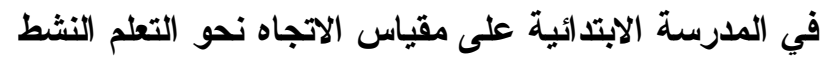


التلاميذ بالتعلم ،وكذلك ما أكدته دراسة نبيل

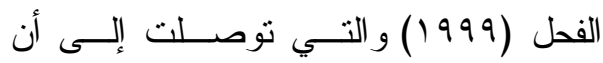
الدافعية للإنجاز لدى الطالبــات المتفوقــات أعلى بكثثر من الطلاب المتفوقين دراســيا، و هــذا يـشجع التلميـذات علــى اســتخدام استر اتيجيات النعلم النشط و أنشطته و أوارق العمل الخاص به وقيــام التلميــذات بــدور

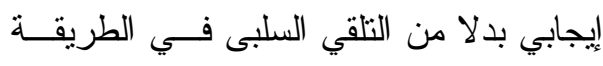

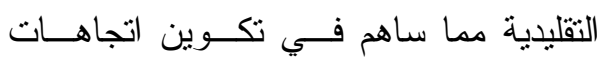
إيجابية نحو التعلم النشط .

وقد تتفوق التلميذات على التلاميذ في الدراسة والاهتمام بالتعلم نتيجــة العوامــلـل

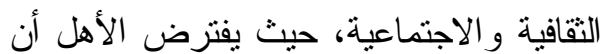
التلاميذ أفضل من التلميذات ممـــا يــدفعهم

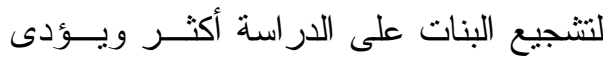

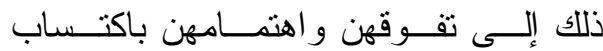

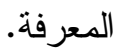

ويستمد التعلم النـشط أهميتـــهـ مــن

النتائج الإيجابية له كما جــاء فــي در اســـة

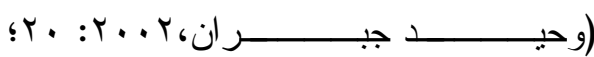

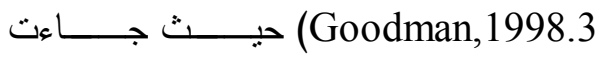
بمجمو عة من النتائج التي تدل علــى أهميـــة التعلم النشط ومن أهمها: زيادة نسبة استبقاء

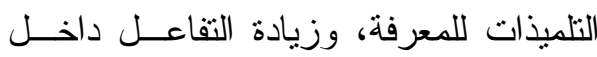
الصف، تتمية اتجاهات التلميذات نحو المادة

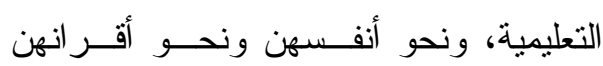
ومعلميهن، وتتمية مهار ات التفكير المختلفـــة ونسة
يتضح من الجدول الــسابق وجــود

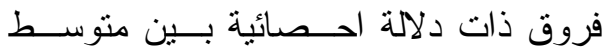
درجات التلاميذ ومنوسط درجات التلميـذات في المدرسة الابتدائية على مقيــاس الاتجـــاه نحو التعلم النشط لصالح التلميذات (المنوسط

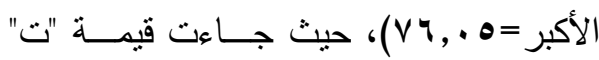

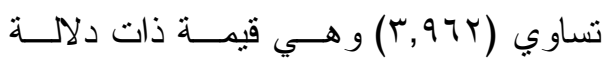
إحصائية عند مستوي دلالة ا ب, ,. مما يشير

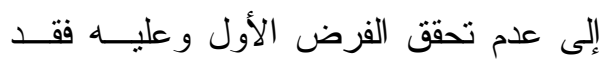

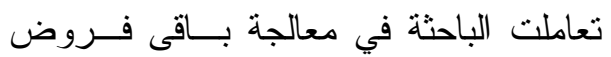

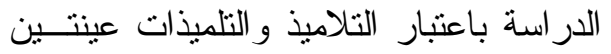
مستقلنين. ويمكن تفسير هذه النتيجة في ضـــوء

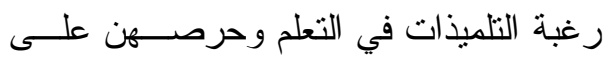
الحضور إلى المدرسة، وعدم التغيب عنهــا،

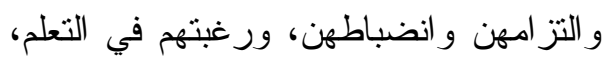

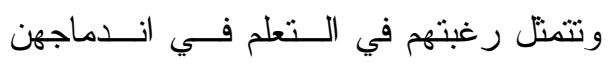

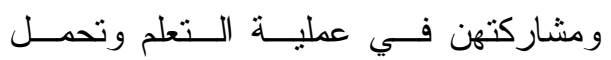

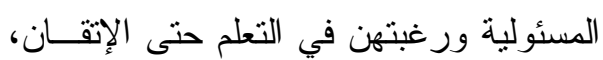

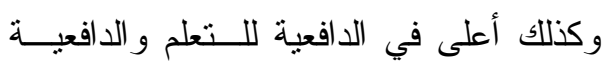
للإنجاز مقارنة بالتلاميذ كانو ا أكثر غيابا من ولن ولئ

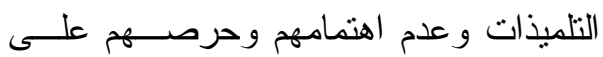

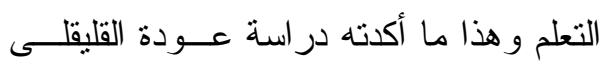

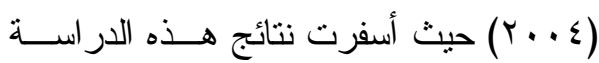
عن وجود فروق ذات دلالة إحــصائية فـي هـي

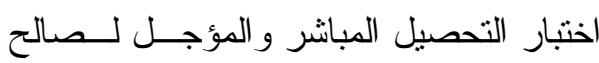
الإناث مما يؤكد اهتمام التلميذات أكثر مـن 
لديهن، وزيادة اهتمامهن و انتباههن وزيــادة نتائج الفرض الثانى:

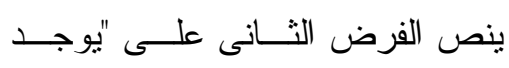

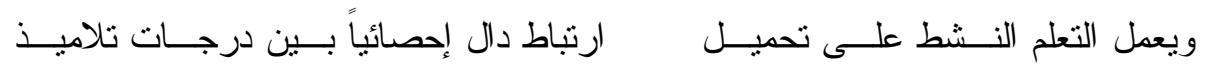

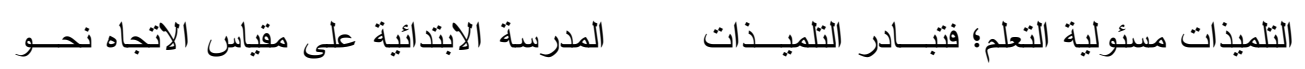
بعمل أنشطة من صنعهن ويقبلن على إجر اء التعلم النشط ودرجاتهم على مقياس الدافعيــة

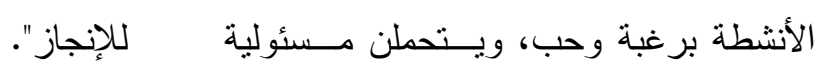

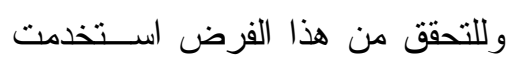

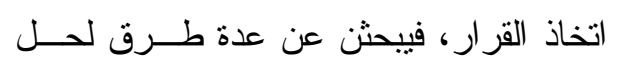

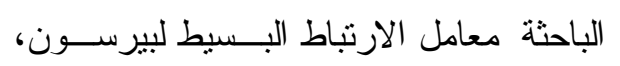

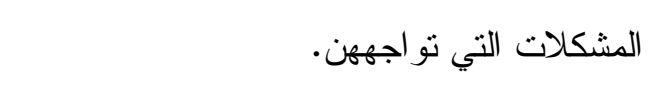

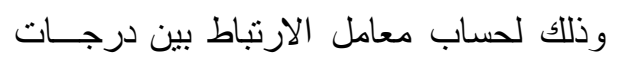
تلاميذ المدرسة الابتدائية على مقياس الاتجاه

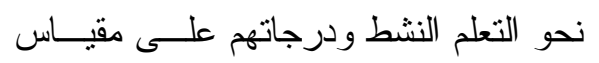

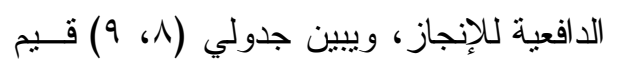
معاملات الارتباط ومستوى دلالتها. تحصيلهن. كما نشعر التلميذات في التعلم النشط

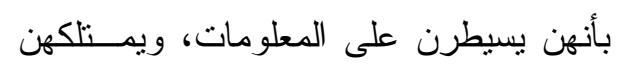
بمعنى أنها تصبح جزء من بنيتهن المعرفية،

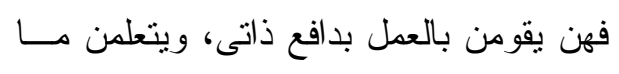

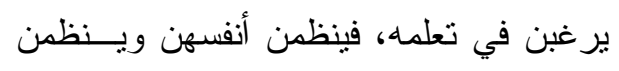

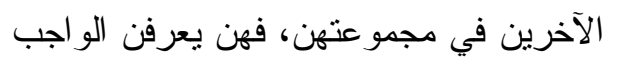

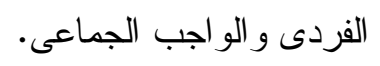
أولاً: بالنسبة لعينة الأكور

جدول (^)

مصفوفة معاملات ارتباط درجات التلاميذ الذكور على مقياس الاتجاه نحو التعلم النشط

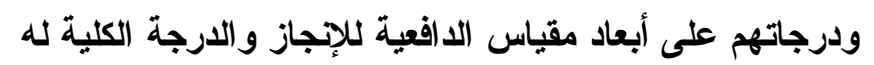

\begin{tabular}{|c|c|c|c|c|c|c|}
\hline لكقياس الدافعية & والتظيم & السعي نحو & المنافسة & المثابرة & الطموح & معاملات الارتباط \\
\hline$* *, \vee \cdot \odot$ & ***, & $* *, 09 \leq$ & ***, r & ***, & $* *, \neg$ ^ & مقياس الاتجاه \\
\hline
\end{tabular}

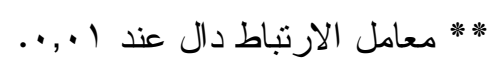
على أبعاد مقياس الدافعية للإنجاز و الدرجـة الكلية له، حيث جاءت قيمة "ر" دالة احصائياً بيضتح من الجدول الــسابق وجــود

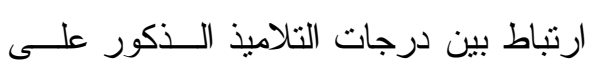

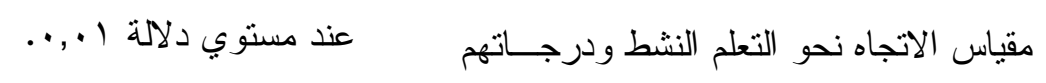


صغيرة؛ فهو يقوم بتعليم قرينه ويقوم بتبــادل

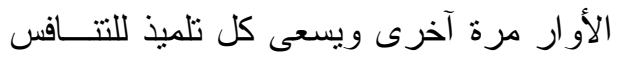
مع زميله في تحمل المسئولية وتحقيق أهدافه،

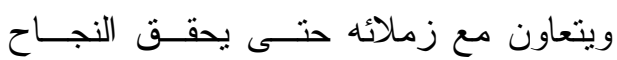

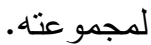

كما أن الدافعية للإنجاز تتـأثز سـلباً

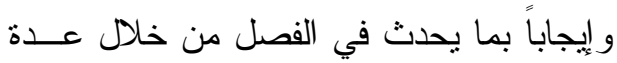

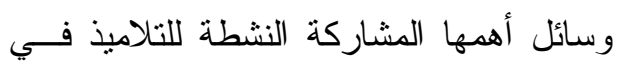
الدرس، و التتوع في وسائل جـــب الانتبــــاه

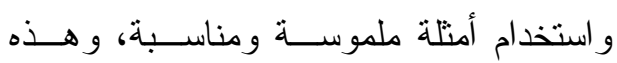

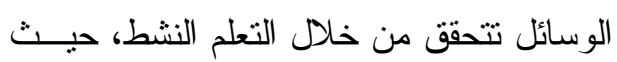

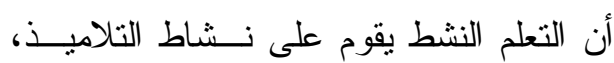
ويخاطب حاجاتهم.

وتتقق هذه النتيجة مع دراسة (حبــاة

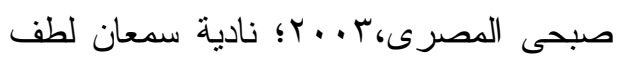

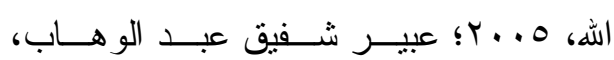

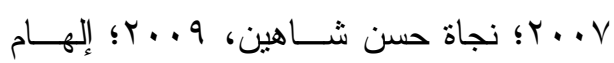

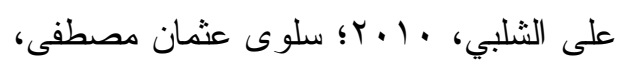
Liu ؛Guvercin\& et al, 2010 . ع \& et al 2011 و التي أنثارت إلى وجــود علاقة بين التعلم النشط و الدافعية للإنجاز، كما أكدت على أن التعلم النشط بنمـــى الدافعيــة للإنجاز لدى التلاميذ عن طريق إثارة دافعيــة

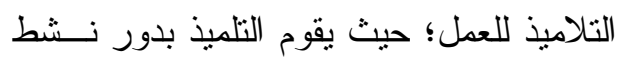
في عملية التعلم.
ويمكن تقسير هذه النتيجة في ضوء

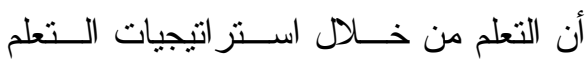
النشط تساعد على اكتساب المعرفة العلميــة

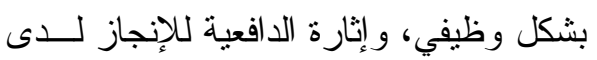

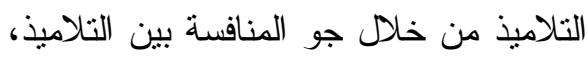
و إكساب التلاميذ مهار ات التتظـــيم و الدقــــة

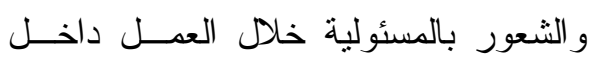
مجموعات ويكسبه المثابرة في الوصول إلى بـ الهدف حيث أن التلميذ يشعر بمسئوليته تجاه

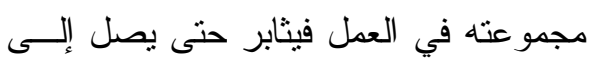

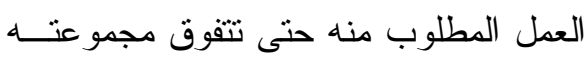
ويكون هو سبب في نجاحها. يوفر التعلم النشط للتلميذ التحـدي،

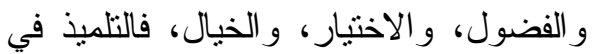
التعلم النشط يقوم بالنشاط من أجل النـشاط

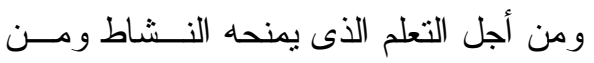

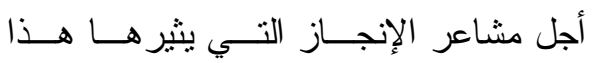
النشاط. ويزيد الاتجاه نحو التعلم النشط مــن

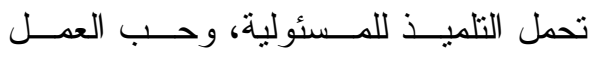
الجماعي، ويساعد التلميذ في تحقيق الامتياز

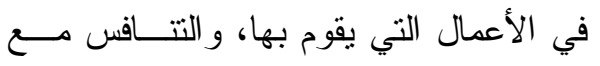

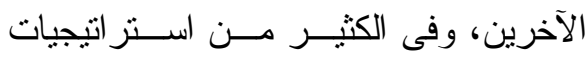
التعلم النشط بتحمل التلمبذ مـسئولية تعلــيم

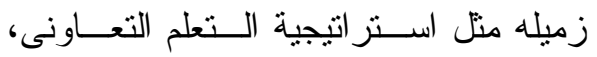

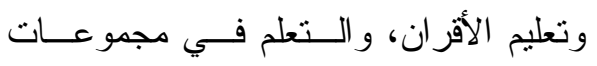




\section{ثاتياً: بالنسبة للإناث}

جدول (9)

مصفوفة معاملات ارتباط درجات التلميذات على مقياس الاتجاه نحو التعلم النشط ودرجاتهم

على أبعاد مقياس الدافعية للإنجاز و الارجة الكلية له له

\begin{tabular}{|c|c|c|c|c|c|c|}
\hline مقياس الدافعية & و التقةي & السعي نحو & المنافسة & المثابرة & الطموح & معاملات الارتباط \\
\hline$* *, v V \varepsilon$ & $* *, T V r$ & $* *, T V r$ & * & אדז, • & \%**, & مقياس الاتجاه \\
\hline
\end{tabular}

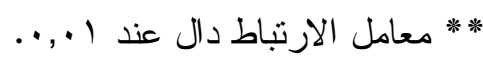

يعتمد التعلم النشط على استراتيجيات

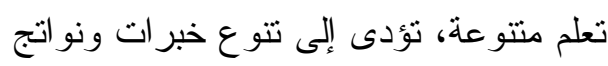

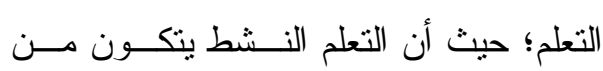

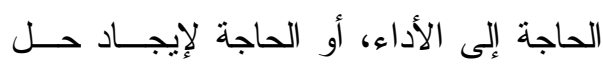

لمشكلة حقيقية أو موقف تعليمى يسنثير تفكير

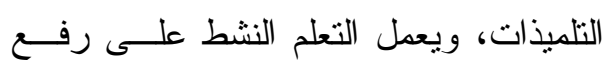

دافعية التلميذات من خلال تحملهم المسئولية،

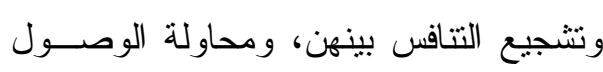

إلى بذل أقصى جهد لديهن، و التعاون بيــنـهن

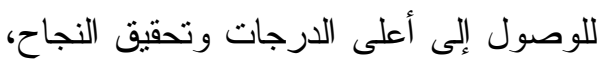

كما يسعى إلى تعليم التلميذات الدقة و التتظيم

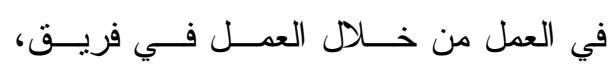

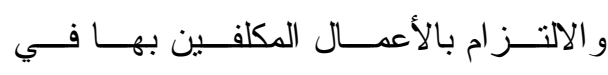

فريقهن.

وفى هذا الصدد يذكر علاء محمود

الــشعر اوى (9901، به (1): أن التعــــاون

يساعد التلاميذ في حل المشكلات ويمكن من
يتضح من الجدول الــسابق وجــود

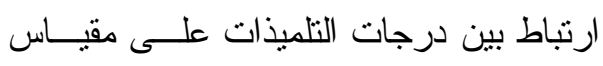

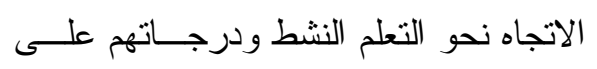
أبعاد مقياس الدافعية للإنجاز و الدرجة الكلية

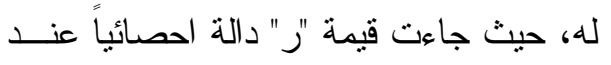
مستوي دلالة ا..,.•.

ويمكن تفسير هذه النتيجة في ضــوء

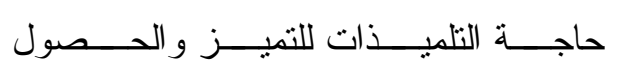
على مر اكز منقدمة في الفـصل الدراسـى

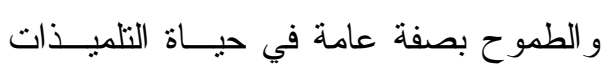

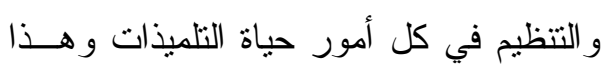

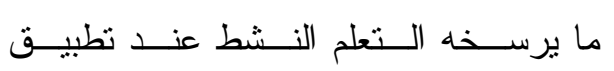

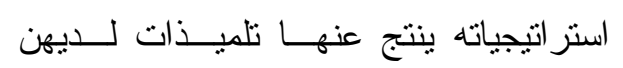

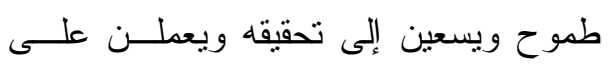

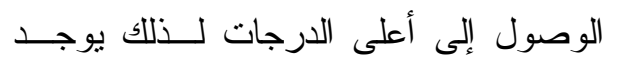

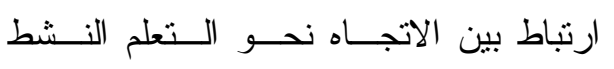

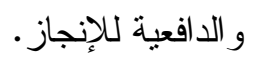




\begin{tabular}{|c|c|}
\hline نتائج الفرض الثالث: & خلاله الوصول إلى مــستويات عليــا مــن \\
\hline ينص الفرض الثالث "أنه توجد فروق & التفكير ، و هذه كلها تمنل دو افع نحو التغلـــب \\
\hline دالة إحصائياً بين منوسط درجات التـلاميــذ & على العقبات والوصول إلى درجات عليا من \\
\hline ذوى الاتجاه الأعلــى نحـــو الــتعلم النـشـط & الإتقان و التقوق على الذات و القيــام بـــالأداء \\
\hline ومتوسط درجات التلاميذ ذوى الاتجاه الأدنى & 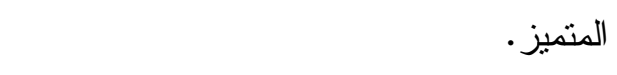 \\
\hline نحو التعلم النــشط علـــى مقيـــاس الدافعيــة & وتتفق هذه النتيجة مع دراسة (على \\
\hline للإنجاز لصـالح ذوى الاتجاه الأعلــى نحـــو & عبد الرحيم حسـانين، 999 ( \\
\hline النعلم النشط". & 2004, Ahomon؛ نادية سمعان لطف اله، \\
\hline وللتحقق من هذا الفرض اســتخدمت & 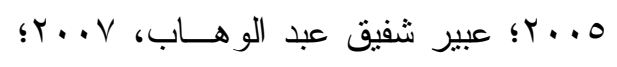 \\
\hline الباحثة اختبار " ت " للمجموعات المــستقلة & ياســـرة محمــــــــــــوب ومعدـــر ارحــيم \\
\hline لتحديد دلالة الفروق بين منوســ درجــات & 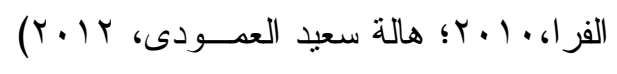 \\
\hline التلاميذ ذوي الاتجاه الأعلــى نحــــ الــتـعلم & حيث أثنارت هذه الدر اسات علــى ارتبــاط \\
\hline النشط ومنوسط درجات التلاميذ ذوي الاتجاه & التعلم النشط بالدافعية للإنجـــاز بــلـ ويقــوم \\
\hline الأدنى نحو التعلم النشط على مقياس الدافعية & بتتميتها لدى التلاميذ من خلال تتمية قـدرة \\
\hline للإنجاز ، ويتضح ذلك من خــلد الجــدول & التلاميذ على تطبيق وتوظيــف المعلومـــات \\
\hline 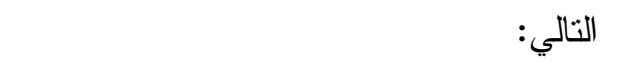 & و المعارف في مو اقف جديدة عن طريق إثارة \\
\hline & دافعية التلاميذ و واستمتاعهم بالعمـلـ، حيــث \\
\hline & \\
\hline
\end{tabular}


أولاً: بالنسبة لعينة الأكور

\section{جدول (1.)}

قيمة " ت " ودلالتها الإحصائية للفروق بين متوسط درجات التلاميذ الذكور ذوي

الاتجاه الأعلى نحو التعلم النشط ومتوسط درجات التلاميذ ذوى الاتجاه الأدنى نحو

التعلم النشط على مقياس الدافعية للإنجاز

\begin{tabular}{|c|c|c|c|c|c|c|c|}
\hline مستوى الالالة & الحرية & قيمة (ت) & الالمر افياري & المتوسط & $\dot{ن}$ & التاتجاه نحو النشط & أبعاد مقياس افعية للإججاز \\
\hline \multirow{2}{*}{$\cdot,+1$} & \multirow{2}{*}{$r}$. & \multirow{2}{*}{11,107} & $r, 191$ & $r_{\cdot, \varepsilon}$ & 1.1 & الاتجاه الأعلى & \multirow{2}{*}{ الطموح } \\
\hline & & & $\varepsilon,+r q$ & $r_{0, r}$ & 1.1 & الاتجاه الأدنى & \\
\hline \multirow{2}{*}{$\cdot,+1$} & \multirow{2}{*}{$r \ldots$} & \multirow{2}{*}{$|r,| \leq \varepsilon$} & $1, v \cdot r$ & ro & 1.1 & الاتجاه الأعلى & \multirow{2}{*}{ المثابرة } \\
\hline & & & $r,\{1 \wedge$ & $r \cdot, r q$ & 1.1 & الاتجاه الأدنى & \\
\hline \multirow{2}{*}{$\cdot,+1$} & \multirow{2}{*}{$r \ldots$} & \multirow{2}{*}{ Ir,rir } & $1,9 \leq V$ & rv,l & 1.1 & الاتجاه الأعلى & \multirow{2}{*}{ المنافسة } \\
\hline & & & $r, \wedge \wedge r$ & $r$ M,Ar & 1.1 & الاتجاه الأدنى & \\
\hline \multirow{2}{*}{$\cdot,+1$} & \multirow{2}{*}{$r .}$. & \multirow{2}{*}{$1 \cdot, \wedge \circ 9$} & $1, \wedge r o$ & $r 0, \leqslant q$ & 1.1 & الاتجاه الأعلى & \multirow{2}{*}{ السعي نحو التميز } \\
\hline & & & $r, 79 V$ & $r 1, \cdot r$ & 1.1 & الاتجاه الأدنى & \\
\hline \multirow{2}{*}{$\cdot,+1$} & \multirow{2}{*}{$r .}$. & \multirow{2}{*}{ IT,IV } & 1,Arr & $r Y, \cdot V$ & 1.1 & الاتجاه الأعلى & \multirow{2}{*}{ التنظيم والدقة } \\
\hline & & & 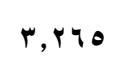 & IV,IV & 1.1 & الاتجاه الأدنى & \\
\hline \multirow{2}{*}{$\cdot,+1$} & \multirow{2}{*}{$r .}$. & \multirow{2}{*}{$|\leq, r| \leq$} & $V, \leqslant r V$ & $1+., 0$ & 1.1 & الاتجاه الأعلى & \multirow{2}{*}{ لمقياس الإفعية } \\
\hline & & & $10, r \wedge \wedge$ & $1 \cdot 0, v_{1}$ & 1.1 & الاتجاه الأدنى & \\
\hline
\end{tabular}

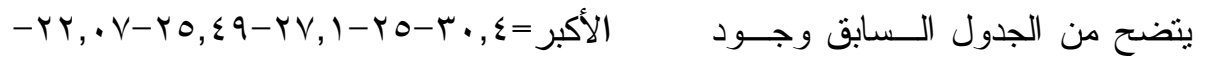

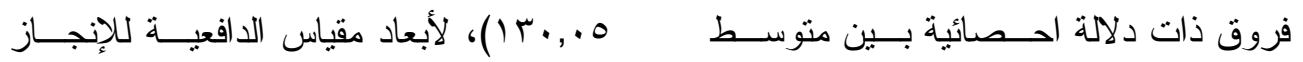

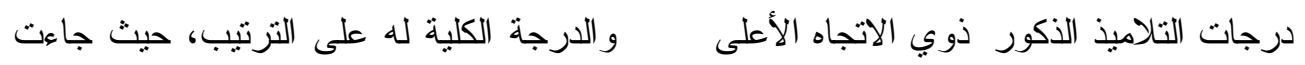

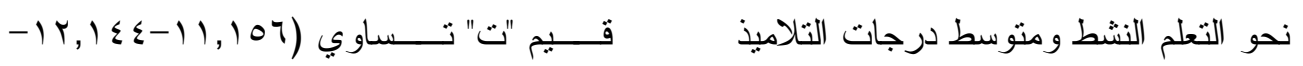

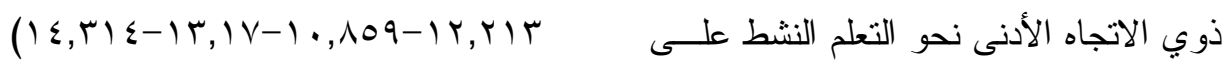

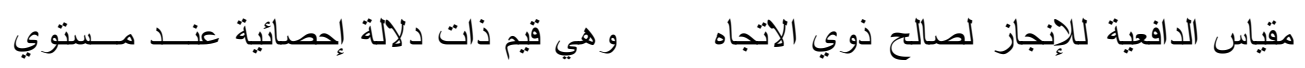

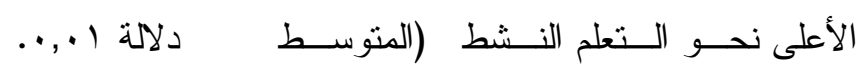


ويتميز التلاميذ ذوى الاتجاه الأعلــى

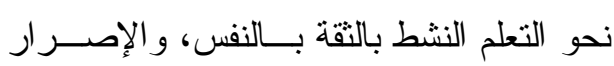
على الوصول إلى الهدف، وتحمل المـسئولية

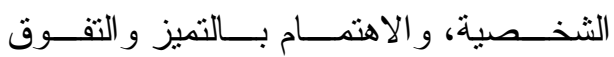
و الحصول على درجات تحــصيلية مرتفعــة، ولديهم الميل للعمل في جماعات، كما يقومون

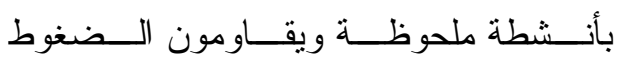
الاجتماعية التي قد يتعرضون لهـــا، ولــــيهم سرعة في أداء المهام، و استقلالية في اتخــاذ القرارات كل هذه الصفات يكتسبها التلميذ من في فئن خلال التعلم النشط. وتتفق هذه النتيجة مع نتائج دراسة كل

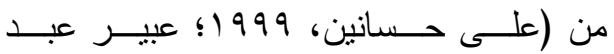

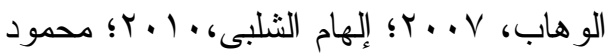

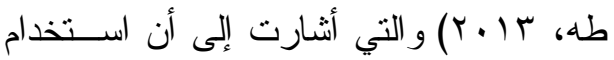

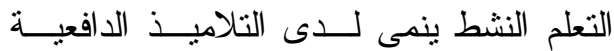

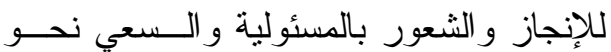

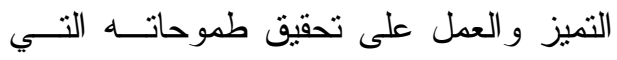
يخطط لها في حياته وحماس التلاميذ لأداء ما

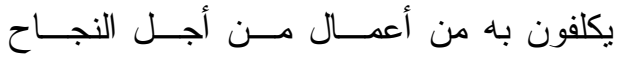
و التقوق.
ويمكن تفسير هذه النتيجة في ضوء

تميز التلاميذ ذوي الاتجاه الأعلى نحو التعلم النشط بالطموح ومحاولة الوصول إلى أعلى لنى لنعيز

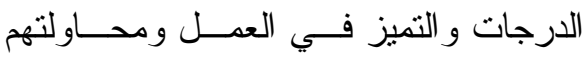
لتنظيم أعمالهم حتى يتسنى لهم الوصول إلى

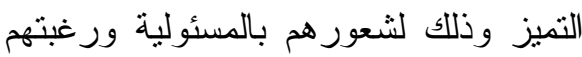
في التعلم حتى درجة الإتقان. كما أن استر اتيجيات الــتعلم النـشط تعمل على استثارة الدافعية للإنجــاز لــدى

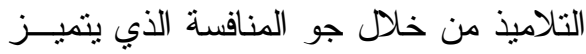
بها التعلم النشط و إكساب التناميذ الرغبة في

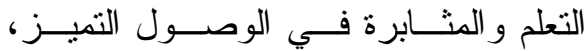
وتعلمهم الثعور بالمـسئولية مــن خــلال استر اتيجيات التعلم النشط التي تتمى لــديهم حب العمل الجماعي و التعاون بينهم وبـين زملائهم. ويعتمد التعلم النشط على بــث روح الثقة في التلاميذ عن طريق اســتراتيجيات

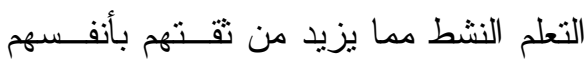
وتتمية دافعيتهم للإنجاز . 
ثانياً: بالنسبة لعينة الإناث

جدول (11)

قيمة " ت " ودلالتها الإحصائية للفروق بين متوسط درجات التلميذات ذوى

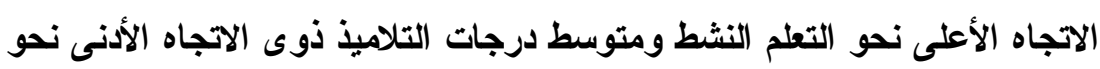

التعلم النشط على مقياس الدافعية للإنجاز

\begin{tabular}{|c|c|c|c|c|c|c|c|}
\hline مستوى & لدرجات & قيمة (ت) & المعياري & المتوسط & ن & الآتجاه نحو النشط & أبعاد مقياس \\
\hline \multirow{2}{*}{$\cdot, ., 1$} & \multirow{2}{*}{ YIT } & \multirow{2}{*}{$1 \leq, . \Delta V$} & גזו, ו & r I, & 1.9 & الاججاه الأعلى & \multirow{2}{*}{ الطموح } \\
\hline & & & ק & ro,or & 1.9 & الاتجاه الأدنى & \\
\hline \multirow{2}{*}{$\cdot, .1$} & \multirow{2}{*}{ Y1T } & \multirow{2}{*}{$1 T, 0 \leqslant r$} & $1, \leqslant .0$ & $r_{0,} \leqslant V$ & 1.9 & الاججاه الأعلى & \multirow{2}{*}{ المثابرة } \\
\hline & & & $r, \varepsilon \cdot V$ & $r \cdot, r q$ & 1.9 & الآجاه الأدنى & \\
\hline \multirow{2}{*}{$\cdot, .1$} & \multirow{2}{*}{ Y1T } & \multirow{2}{*}{ IT,qY4 } & I, qYV & $r v, 0 \leq$ & 1.9 & الاتجاه الأعلى & \multirow{2}{*}{ المنافسة } \\
\hline & & & $r, \leqslant V V$ & rY,rs & 1.9 & الاتجاه الأدنى & \\
\hline \multirow{2}{*}{$\cdot, \cdot 1$} & \multirow{2}{*}{ YIT } & \multirow{2}{*}{$1 T, 01 r$} & 1, rvq & rז, & 1.9 & الاتجاه الأعلى & \multirow{2}{*}{ السعي نحو } \\
\hline & & & $r, 1 \cdot r$ & $r \mid, r \leq$ & 1.9 & الاتجاه الأدنى & \\
\hline \multirow{2}{*}{$\cdot, .1$} & \multirow{2}{*}{ YIT } & \multirow{2}{*}{$10, . \leq \leqslant$} & $1,0 \mathrm{~V} \leqslant$ & rr, lo & 1.9 & الاتجاه الأعلى & \multirow{2}{*}{ التنظيم و الدقة } \\
\hline & & & $r, \Lambda 11$ & $1 v, 0$. & 1.9 & الاتجاه الأدنى & \\
\hline \multirow{2}{*}{$\cdot, .1$} & \multirow{2}{*}{ YIT } & \multirow{2}{*}{$\mid V, 0 \leq \varepsilon$} & $0,0 \vee \wedge$ & Irr,. & 1.9 & الآجاه الأعلى & \multirow{2}{*}{ للإججاز ككل الدافعية } \\
\hline & & & Ir,V. & l. V,r. & 1.9 & الاتجاه الأدنى & \\
\hline
\end{tabular}

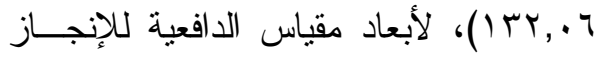

يتضح من الجدول الــسابق وجــود

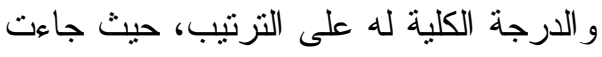

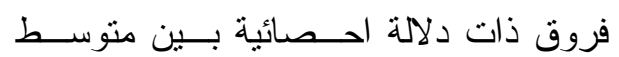

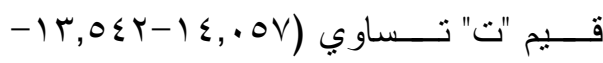

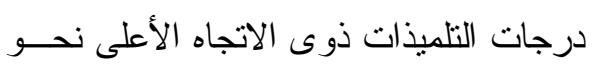

$(1 V, 0 \leq \varepsilon-10,0 \leq \varepsilon-1 r, 0) r-1 r, 9 r 4$

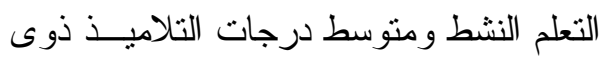

وهي قيم ذات دلالة إحصائية عند مسستوي

الاتجاه الأدنى نحو التعلم النشط على مقياس

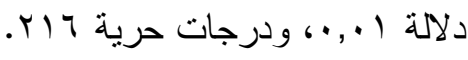

ويمكن تقسير هذه النتيجة في ضـــوء

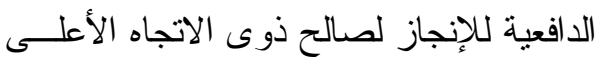

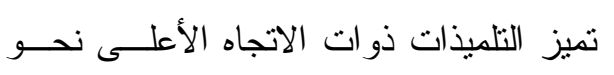

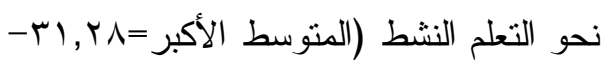

$-Y Y, 10-Y 0, T r-Y V, 0 \leqslant-Y 0, \Sigma V$ 


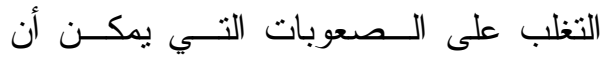

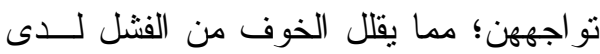
التلميذات ويعزز لديهن الرغبة فــي إعـادة فئاد

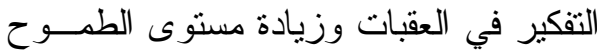

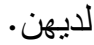

وتتفق نتيجة هذا الفرض مع دراســـة

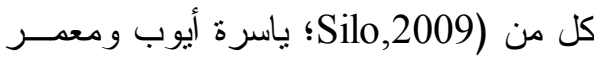

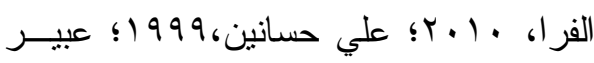

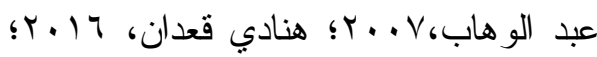

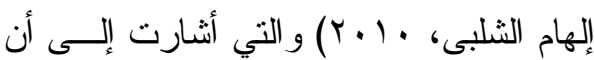
التعلم النشط يزيد من دافعية التلاميذ للإنجاز وينميها لذلك يكون ذوي الاتجاه الأعلى نحو

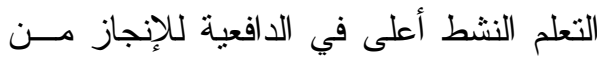

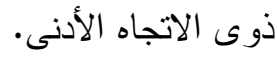

$$
\text { توصيات البحث: }
$$

•- ضرورة تتمية الاتجاه الإيجابي للتناميذ نحو التعلم النشط أثثاء عملية التعلم من

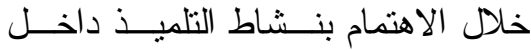
الفصل ودوره الإيجابي في مهام التعلم.

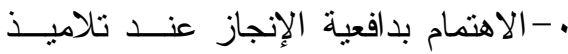

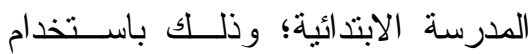
التعلم النشط.

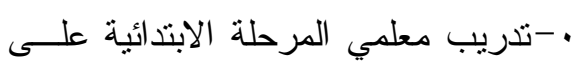
استخدام استراتيجيات التعلم النشط فـي لتئي تدريس المو اد المختلفة.

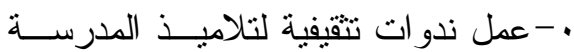

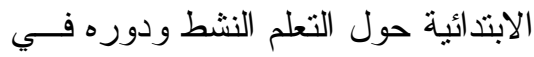
تعلمه و اكتسابهم المهارات الحياتية.
التعلم النشط بتحملهن المسئولية، و إصرارهن على الوصول إلى أهدافهن، وميلهن لإنجــاز

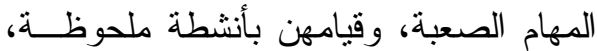

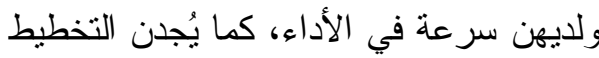

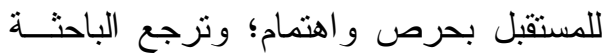
ذللك لأن التعلم النشط بساهم في زيادة قــدرة التلاميذ على الاحتفاظ بالتعلم وزيادة الدافعية للإنجاز من خلال تتمية قدرة التلاميذ على لـى العي

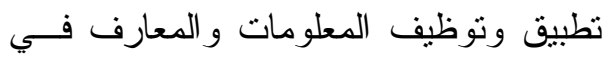
مو اقف جددة عن طريق إثارة دافعية التلاميذ و استمتاعهم بالعمل، حيث يقومون بدور نشط طن في عملية التعلم.

ففي التعلم النشط تكــــن التلميــذات

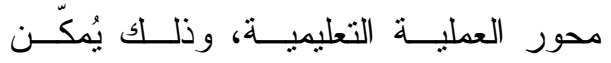
التلميذات من التعبير عن آرائهن و المشاركة ودة

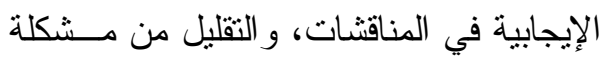

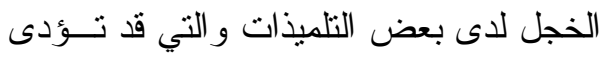

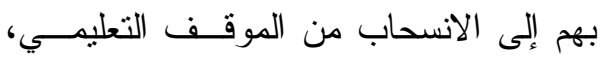

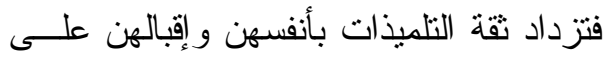

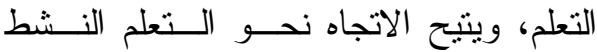
الفرصة لجعل مصدر دافعية التلميذات داخلية

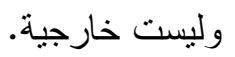
ويعتمد التعلم النشط على بــث روح الثقة في التلميذات عن طريق اســتراتيجيات

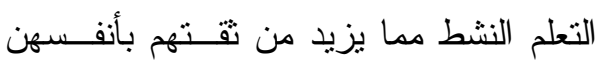
ونتمية دافعيتهن للإنجاز .

كذلك فإن قيام المعلم بدور الموجـهـ

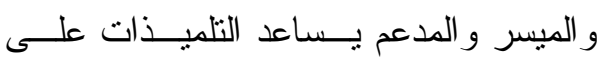


• - الاهتمام بالأنشطة التزبوية التي نتمـى مراجع البحث:

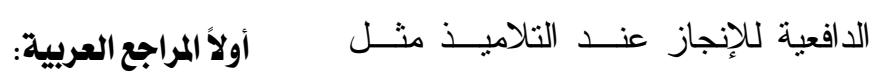

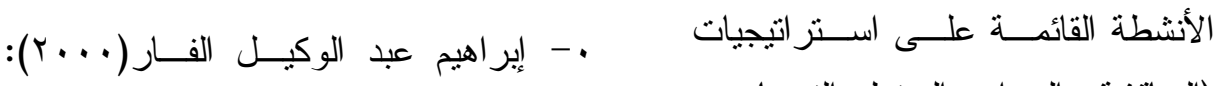

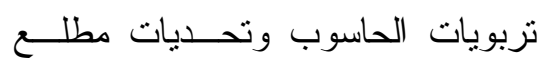

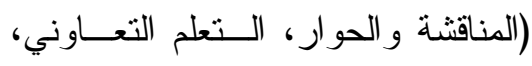

القرن الحادي و العشرين. طץ، القاهرة:

$$
\text { دار الفكر العربي. }
$$

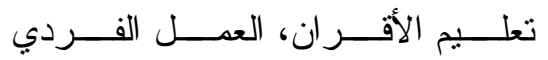

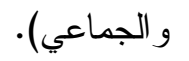

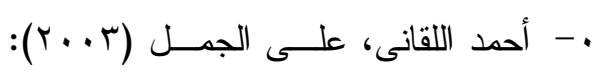

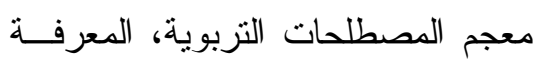

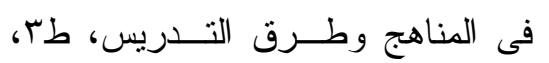
القاهرة: المالم الكتاب.

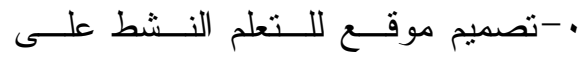

الإنترنت؛ وذللك ليستقيد منه المعلمـين

و المعلمات، تُعرض فيه استـتر انتيجيات

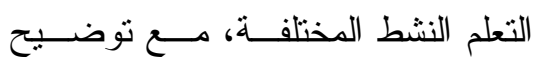

مفصل لكـلـل اســتر اتيجية: ماهيتهـــا،

• - أسامة محمد سيد، عباس حلمي الجمــل

ونماذج لكل استر اتيجية، وكيفية تطبيقها

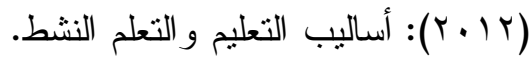

في مر احل التعليم المختلفة.

دسوق:دار العلــم و الإيمــان للنــشر

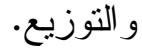

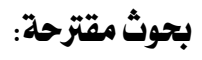

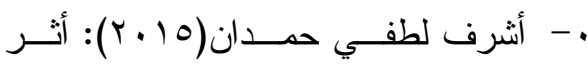

الدمج على مفهــوم الــذات ودافعيــة

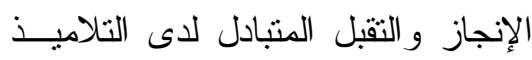

ذوي الإعاقة السمعية و العاديين، رسالة

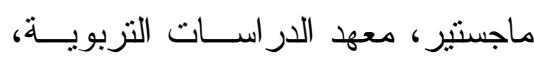

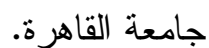

•- إلهام علي الثبلي(· • ( ب): أثز استخدام

•- در اسة الاتجاه نحو التعلم النشط و أثزه

على الدافعية للإنجاز لمر احل تعليمية

مختلفة.

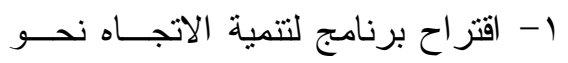

التعلم النشط في المرحلة الابتدائية.

r- دراسة اتجاه المعلمين نحو ممارستهم

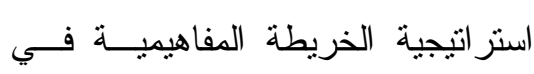

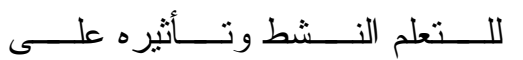

تلامبذهم.

تحصيل طلبة الصف التاســـع للمفــاهيم

ץ- دراسة الدافعية للإنجــاز وعلاقتهــا

العلمية في مادة الأحياء ودافع للإنجــاز

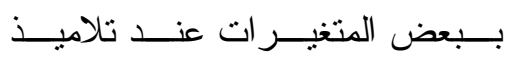

$$
\text { المدرسة الابتدائية. }
$$

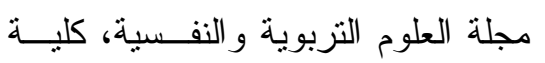

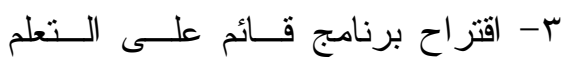

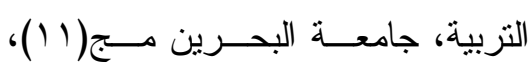

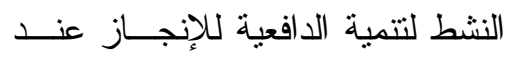

$$
.10 .-11 \mathrm{~V} ،(\mathrm{r}) \varepsilon
$$

التناميذ. 
حول الطالــب، المنــصورة: المكتبـــة العصرية للنشر و التوزيع. - سلام سيد سلام(999 (19): تقنين اختبـــار "مور" للاتجاهات نحو العلــوم ونحــو تدريس العلوم و استجوبه للكثف عـنـ التغير في الاتجاهات لدى معلمى العلوم قبل التخرج بجامعة الملك سعود، مجلة البحث بالتزبية ،ع(ع)، ج(1) (1) ، (10-0r.

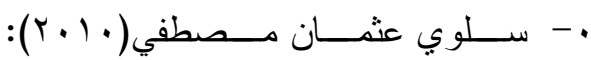

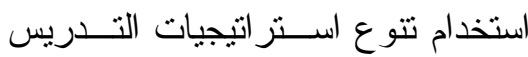
Instructional Strategies Differentiated في مجال الأشـــال الفنية لتتمية الدافع للإنجاز و الاتجاه نحو

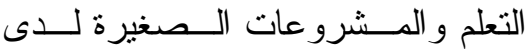
تلميذات مدارس الفصل الواحد متعـدد المستويات، مجلة دراسات في المناهج

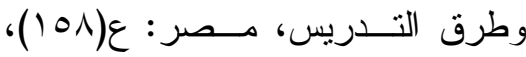
ror-191 •- سهير كامل أحمد (1 (. ب): علم النفس الاجتماعي بــين النظريــة و التطبيــق. الإسكندرية، مركز الإسكندرية للكتاب.

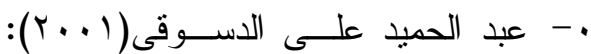
تأثثير المناخ النفسى الاجتمـــاعى كمـــا

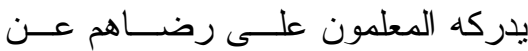
عملهم واتجاهاتهم نحو الابتكــار فـي لـي المرحلة الثانوية، رسالة ماجستير غيــر

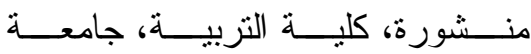

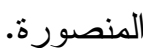

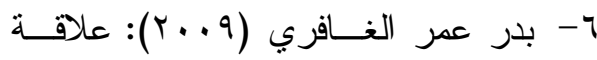

الدافعية نحو العمل ببعض المتغيــرات الثخصية والوظيفية لاى الموظفين في دولة الكويت، مجلة البحوث التزبويــة،

$$
\text { .17V-110 (1V) ع }
$$
- - جودة أحمد سعادة، إسماعيل جابر أبــو

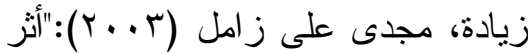

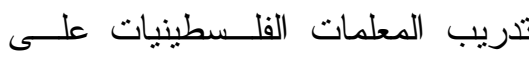

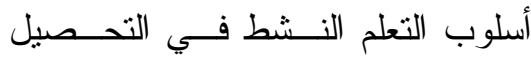

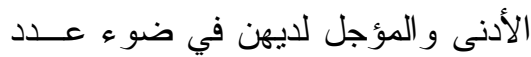

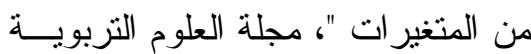

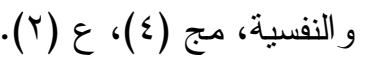

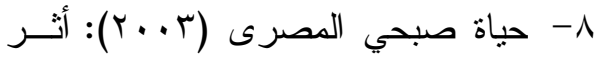
استخدام الخـــر ائط المخروطيــة علــى تحصيل طلبة الصف التاسع في مسادة

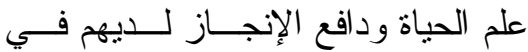

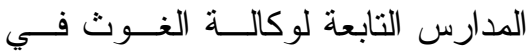
محافظة نابلس، رسالة ماجستير غبــر

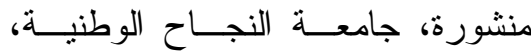
نابلس، فلسطين.

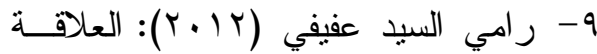
بين قوة الأنا وكل من الكفاءة الأكاديمية و الكفاءة الاجتماعية ودافعيــة الإنجــاز لاى طلبة الجامعة، رســالة ماجسستير غير منشورة، معهد الدر اسات التزبوية،

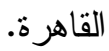

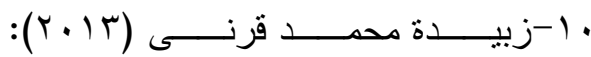
استر اتيجيات التعلم النـشطط المتمركـز 
• Y-على بن محمد مرعى (T . . Y): دافعية الإنجاز الدر سي وقلق الاختبار وبعض المتغير ات الأكاديمية لدى طلاب كليـــة المعلمين في جاز ان، رسالة ماجسستير غير منشورة، جامعة أم القرى. (ب-على عبد الــرحيم حسسانين(999 (1): فعالية استخدام التعلم التعاوني و التعلــبم الفردي في تدريس الرياضــيات علــى تتمية التفكير الابتكاري و الدافع للإنجاز

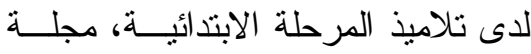

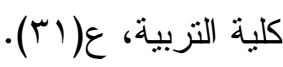

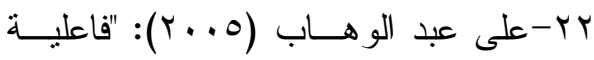
استخدام بعــض اســتر اتيجيات الــتعلم النشط فــي تـــريس التـاريخ لتتميـــة مهار ات التفكير التاريخي و الاتجاه نحو

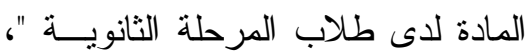

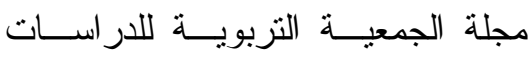

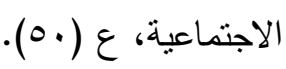

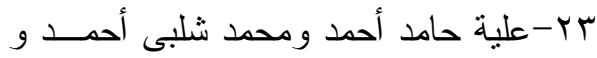

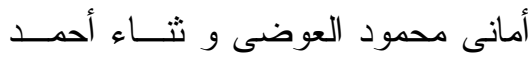
جمعة و إيمان سيد رمضان وصلاح عبد

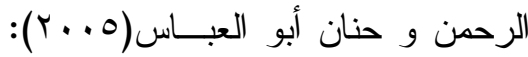
الموسوعة المرجعية للتعلم النشط، دليل

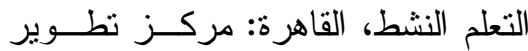
المناهج و المو اد التعليمية.

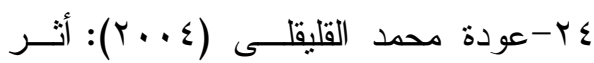
استخدام طر ائق تــدريس المحاضـــرة

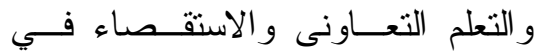

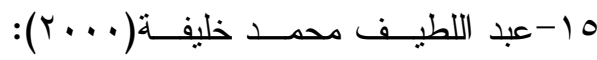

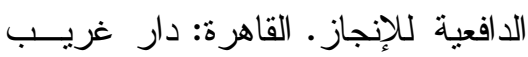
للطباعة و النشر و التوزيع.

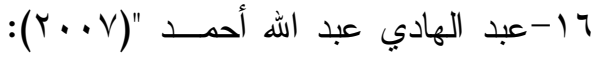

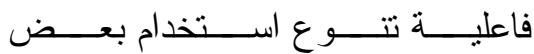
استر اتيجيات التعلم النشط في تــدريس الاقتصاد على التحصيل و الاتجاه نحــو دراسة الاقتصاد لدى طلاب المرحلـــة

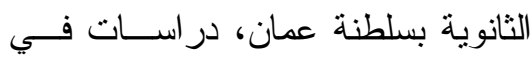
المناهج وطرق التـدريس، ع (·r I (l)، . $19-7$. IV

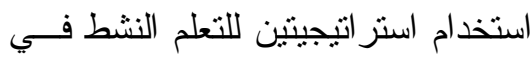

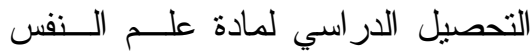
و الدافعية للإنجاز لدي طلاب المرحلـــة

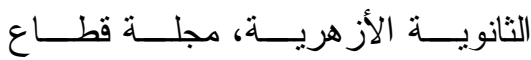

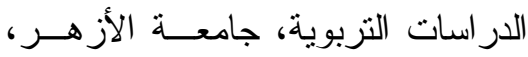
RYI-IV. • (l)

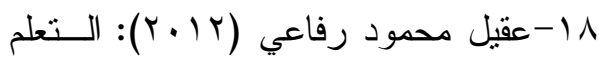
النــشط. الإســــندرية: دار الجامعـــة

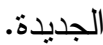

1- علاء محمــود الـشعراوي (1990):

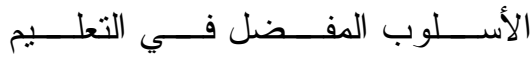
وعلاقته بالاتجاه نحو المدرســة لــدى تلاميذ الحلقة الثانية بالتعليم الأساسـي، ولهي، مجلة البحوث النفسية و التربوية، كليــة

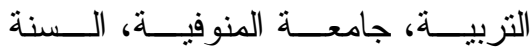

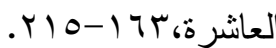




$$
\begin{aligned}
& \text { المصرية للار اسات النفسية، مج(ع ())، } \\
& \text { و اتجاهاتهم نحو ها في مبحــث التربيـة }
\end{aligned}
$$

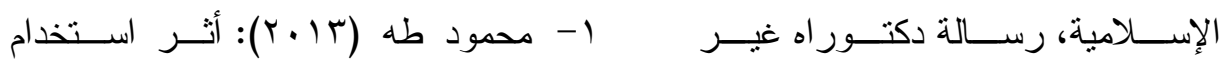

$$
\begin{aligned}
& \text { استر اتيجية توليفيه قائمة علــى الــتـعلم } \\
& \text { النشط في التحصيل الأكاديمى وتعـديل }
\end{aligned}
$$

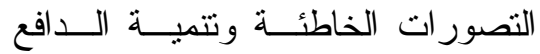

$$
\begin{aligned}
& \text { للإنجاز لدى طــلاب الــصف الثــاني }
\end{aligned}
$$

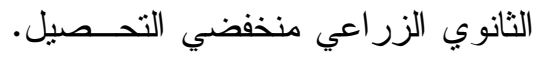

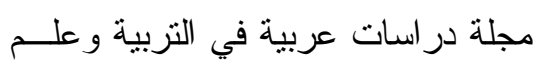

$$
\begin{aligned}
& \text { النفس، جY، ع) ع ( }
\end{aligned}
$$

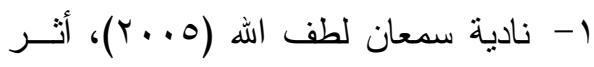

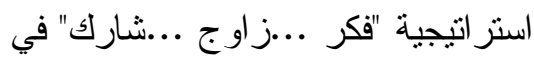

$$
\begin{aligned}
& \text { التحصيل و التفكير الابتكاري ودافعيــة }
\end{aligned}
$$

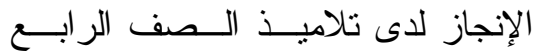

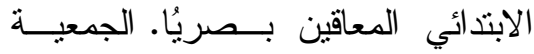

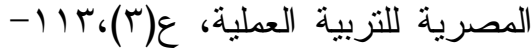

$$
\begin{aligned}
& .174 \\
& \text { 1- نبيل محمد الفحـل (999 ()): دراســـة } \\
& \text { مقارنة بين المتفوقين و العـاديين مــن }
\end{aligned}
$$

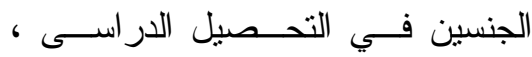

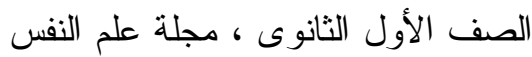

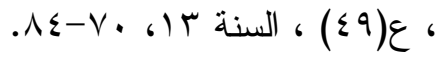

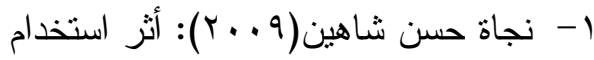

$$
\begin{aligned}
& \text { بعض استراتيجيات التعلم النشط علـي }
\end{aligned}
$$

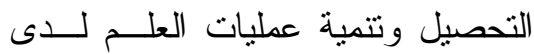

$$
\begin{aligned}
& \text { تلاميذ الصف الرابع الابتدائي، مجلـــة }
\end{aligned}
$$

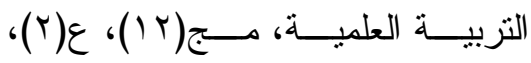

$$
\begin{aligned}
& .109-1 \mathrm{KV}
\end{aligned}
$$

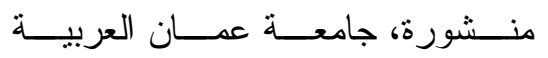

$$
\begin{aligned}
& \text { للار اسات العليا، عمان، الأردن. }
\end{aligned}
$$

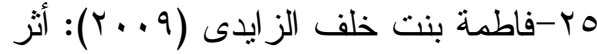

$$
\begin{aligned}
& \text { التعلم النشط في تتمية التفكير الابتكارى } \\
& \text { و التحصيل الدراسى بمادة العلوم لــدى }
\end{aligned}
$$

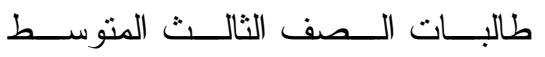

$$
\begin{aligned}
& \text { بالمـــدارس الحكوميـــة بمدينــة مكـــة } \\
& \text { المكرمة، رسالة ماجستير غبر منشورة، }
\end{aligned}
$$

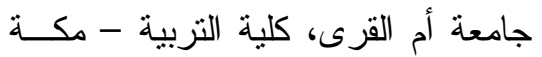

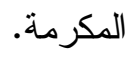

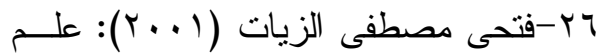

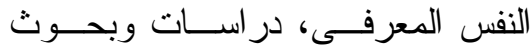

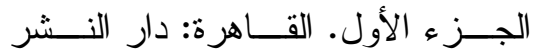

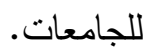

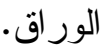

$$
\begin{aligned}
& \text { الأردن: دار المسبرة. }
\end{aligned}
$$


,Hacettepe University Journal of Education, (39), 233-247.

39- Larson,D\&Ahomon,A(2004):

Active Learning in a Finnish Engineering University

Course, Europen Journal of Engineering

Education,Vol.(29),No.(4),pp. 521-532.

40- Liu,M.,Horton,L.,Olmanson,J., \& Toprac,p.(2011): A Study of Learning and Motivation in a New Media Enriched Environment for Middle School Science. Journal Articles, Reports -Research, Educational Technology Reseach and Development. Vol.(59), No.(2),pp.249-265.

41- Sila,O.(2009):Engaging Elementary Preservice Teachers with Active Learning Teaching Methodologies, Journal Of Teacher Educator, Vol.(44), No.(2),PP.113-125.

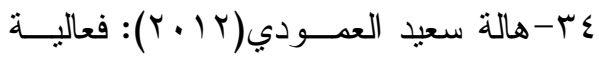

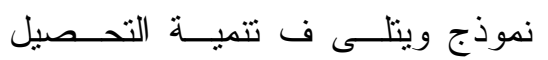

$$
\begin{aligned}
& \text { ومهار ات توليد المعلومات في الكيمياء }
\end{aligned}
$$

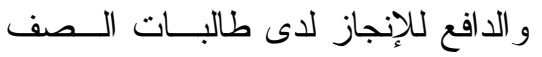

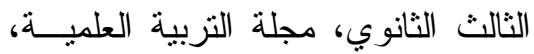

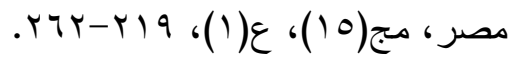

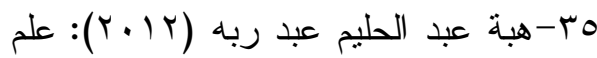

$$
\begin{aligned}
& \text { النفس النشط. الإسكندرية: دار الجامعة }
\end{aligned}
$$

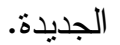

بس-ياسرة محمد أيوب، معمر ارحيم الفــرا

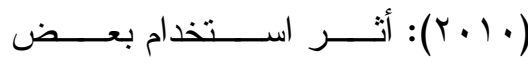

استر اتيجيات التعلم النشط على مستوى

دافعية الإنجاز و الثقة بالنفس و التحصيل

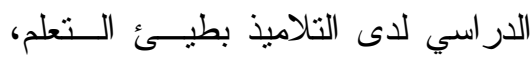

مجلة جامعة الأز هر بغزة، سلسة العلوم

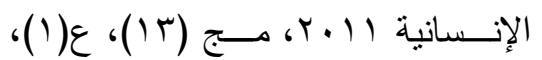

$.1 \% \cdot-\lambda q$

V

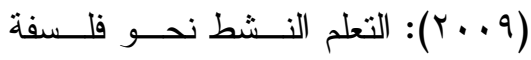

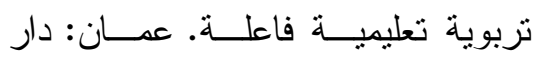

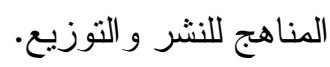

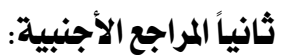

38- Guverin,O.et al.,(2010): A Croos Age Study of Elementary Students. Motivation towards Science Learning Science Learning 